\title{
A new approach to quantify and map carbon stored, sequestered and emissions avoided by urban forests
}

\author{
E. Gregory McPherson ${ }^{\mathrm{a}, *}{ }^{\text {, Qingfu Xiao }}{ }^{\mathrm{b}}$, Elena Aguaron ${ }^{\mathrm{c}}$ \\ a USDA Forest Service, Pacific Southwest Research Station, 1731 Research Park Drive, Davis, CA 95616, United States \\ b UC Davis, Department of Land, Air \&' Water Resources, United States \\ c CSU Fresno, Department of Plant Science, United States
}

\section{H I G H L I G H T S}

- Species composition, basal area and development patterns influence carbon.

- Carbon storage was high in Sacramento due to native oaks with high wood density.

- Avoided emissions were high in Los Angeles due to trees shading multiple buildings.

- California's urban forests account for 2 percent of $C$ stored by forests statewide.

- California's urban forests account for 12 percent of $C$ sequestered by forests statewide.

\section{A R T I C L E I N F O}

\section{Article history:}

Received 5 October 2012

Received in revised form 3 August 2013

Accepted 14 August 2013

Available online 8 September 2013

\section{Keywords:}

Carbon density

Urban tree canopy

Transfer function

Urban forest structure

Wood density

Climate action planning

\begin{abstract}
A B S T R A C T
This paper describes the use of field surveys, biometric information for urban tree species and remote sensing to quantify and map carbon (C) storage, sequestration and avoided emissions from energy savings. Its primary contribution is methodological; the derivation and application of urban tree canopy (UTC) based transfer functions ( $\mathrm{t} \mathrm{Cha}^{-1} \mathrm{UTC}$ ). Findings for Los Angeles and Sacramento illustrate the complex role of regional and local determinants. Although average tree density and size were substantially greater in Los Angeles, the mean C storage density $\left(8.15 \mathrm{tha}^{-1}\right)$ was 53 percent of Sacramento's $\left(15.4 \mathrm{tha}^{-1}\right)$. In Sacramento, native oaks with very high wood densities $\left(815 \mathrm{~kg} \mathrm{~m}^{-3}\right)$ accounted for 30 percent of total basal area. In Los Angeles, the most dominant taxa had relatively low wood densities $\left(350-550 \mathrm{~kg} \mathrm{~m}^{-3}\right)$. The inclusion of relatively more wooded land in the Sacramento study area may partially explain higher C storage levels. In Los Angeles, where development is relatively dense, 14 percent of all trees surveyed shaded more than one building compared to only 2 percent in Sacramento. Consequently, the transfer function for avoided emissions in Los Angeles $\left(2.77 \mathrm{tha}^{-1} \mathrm{UTC} \mathrm{yr}^{-1}\right)$ exceeded Sacramento ( $2.72 \mathrm{tha}^{-1} \mathrm{UTC} \mathrm{yr}^{-1}$ ). The approach described here improves $\mathrm{C}$ estimates and increases the resolution at which $C$ can be mapped across a region. It can be used to map baseline $C$ storage levels for climate action planning, identify conservation areas where UTC densities are highest and determine where opportunities for expanding UTC are greatest.
\end{abstract}

Published by Elsevier B.V.

\section{Introduction}

Carbon stored in urban forests is not typically included in national, statewide and regional inventories of greenhouse gas (GHG) emissions and sinks, perhaps because cities make up a small fraction of total land area and intensive management of trees can release large amounts of GHGs (Ryan et al., 2010). Although

\footnotetext{
* Corresponding author. Tel.: +1 530759 1723; fax: +1 5307561409 .

E-mail addresses: gmcpherson@fs.fed.us, egmcpherson@ucdavis.edu (E.G. McPherson), qxiao@Cdavis.Edu (Q.Xiao), eaguaronfuente@Csufresno.Edu (E. Aguaron).
}

urbanized areas account for 3 percent of total land area and 81 percent of total population in the US (Cox, 2012), Heath, Smith, Skog, Nowak, and Woodall (2011) found that trees in US cities sequester about 14 percent of the amount of carbon (C) sequestered by US forests. Although relatively small in stature, urban forests store substantial amounts of carbon. Accurate quantification and mapping of these stocks is fundamental to the inclusion of urban forestry in local climate action plans and carbon offset markets. This study combines field surveys, biometric information for urban tree species, Geographic Information System (GIS) data sets and remote sensing of urban tree canopy (UTC) to quantify and map C stored, sequestered and emissions avoided in two urban forests. By incorporating age-related differences among census block groups 
that influence tree species composition and stand structure, this approach improves $C$ estimates and increases the resolution at which $C$ can be mapped across a region.

\subsection{Urban forest project protocols}

In California, a cap and trade program began in 2012 to drive investment in cleaner fuels and more efficient energy use. The Compliance Offset Protocol for Urban Forest Projects is one of four protocols that will guide carbon offset projects (California Air Resources Board, 2011). The current protocol focuses on offsets from tree planting projects, but the Climate Action Reserve (2010) is exploring development of a second protocol based on field surveys that are linked with urban tree canopy (UTC) mapped with remote sensing. Urban tree canopy (UTC), defined as the layer of leaves, branches and stems that cover the ground when viewed from above, is a metric used to quantify the areal extent of the urban forest (Raciti et al., 2006). Using UTC as a metric for C storage has the advantage of being readily measured and tracked over time at high spatial resolution and with increasing accuracy as technologies develop. Mapping the spatial distribution of existing and additional stocks can provide the basis for quantifying and reporting changes in $\mathrm{C}$ storage, as well as for planning and managing urban forests to increase $C$ stocks. For example, maps can be used to locate areas with the greatest potential for increasing tree canopy through tree planting, as well as areas where the foremost need is to preserve C stored in existing canopy (Escobedo, Varela, Zhao, Wagner, \& Zipperer, 2010; Myeong, Nowak, \& Duggin, 2006).

\subsection{Transfer functions}

Broadly speaking, transfer function is a term used to describe the transfer of data for a particular "study site" to a "policy site" for which little or no data exist (Brookshire \& Neill, 1992; Downing \& Ozuna, 1996). In this study, transfer functions are defined as field plot-based measures of $C$ per hectare UTC $\left(t\right.$ ha $^{-1}$ tree canopy cover) that are aggregated and applied to a region by land use class.

Two studies have derived and applied UTC-based transfer functions. Nowak and Greenfield (2010b) calculated mean UTC storage (333.7 tha $\mathrm{t}^{-1}$ UTC) and sequestration (11.0 tha $\mathrm{h}^{-1}$ UTC) densities using 2001 NLCD imagery and field sampling in 17 US cities. Their values may be relatively high because the classification process was found to significantly underestimate UTC (Nowak \& Greenfield, 2010a). Strohbach and Haase (2012) used high resolution orthophotos to classify UTC and intensive UFORE field sampling to estimate aboveground carbon and UTC densities for 19 land use classes. They compared C estimates derived using UTC and land use class alone and found that UTC-based estimates provided higher accuracy, greater precision and improved spatial detail. The UTC-based approach eliminated variation in UTC within land use classes, an important source of error. Because field plot sampling did not fully capture the extent of UTC for each land use class, land use based $C$ storage estimates had large standard errors in areas where UTC was highly heterogeneous, such as town centers.

To derive UTC-based transfer functions, C storage, sequestration and avoided emission values are calculated for trees in each plot and divided by the plot's UTC. Plot data are aggregated by land use class and descriptive statistics are applied to determine sample means and standard errors. Different values reflect different stand structures and dynamics that influence $C$. For instance, the $C$ storage transfer function for a hectare of UTC in an old residential neighborhood will be relatively high when the stand consists of mature oaks (Quercus sp.) and a lush understory. In contrast, the transfer function for a hectare of UTC in a new residential area will be lower when the stand is characterized by juvenile pear (Pyrus sp.) trees with a sparse understory.
The value of a transfer function reflects species composition and attributes of stand structure. Stand attributes, such as the vertical layering of woody biomass in strata, tree density and basal area influence the amount of biomass per hectare UTC and the resulting value of a transfer function. Species is important because of its influence on the tree's biomass and partitioning into roots, bole, branches, stems and foliage. Also, the amount of biomass converted into carbon depends on the species' wood density, which can vary widely among species.

The transfer function for each land use class is transferred to the UTC delineated from imagery for the corresponding land use. Using GIS capabilities, $C$ values are mapped and summed based on the amount of UTC in each land use class. These maps provide spatially explicit information on the distribution of urban forest $C$ for planning and management purposes.

\subsection{Regional and local determinants}

The magnitude of $\mathrm{C}$ stored, sequestered and avoided emissions by urban forests depends on regional and local determinants. Regional context influences climate, soil, potential vegetation and urban morphology (Nowak et al., 1996; Sanders, 1984). Desert cities can have lower overall $C$ storage densities than cities in temperate climates because unmanaged open space in deserts contains less biomass than in forest biomes such as Atlanta and Baltimore (Yesilonis \& Pouyat, 2012). Older, densely developed cities can contain less growing space for urban vegetation that stores less $C$ than sprawling cities (Zipperer, Sisinni, Pouyat, \& Foresman, 1997).

Local determinants of urban forest $C$ storage include species composition, age structure, stand density and tree management practices, as well as neighborhood age and land use (Zhao, Kong, Escobedo, \& Gao, 2010). Carbon storage typically decreases as impervious surfaces and land development intensity increases. In Leipzig for example, land uses with the highest $\mathrm{C}$ storage densities were cemeteries, parks and single-family residential areas, while commercial, industrial and multifamily residential had lower C densities (Strohbach \& Haase, 2012).

Each urban forest can be viewed as a mosaic of neighborhood stands with structural features that reflect historic changes in species preferences, planting practices, land development patterns, and tree conservation and planting policies (Berland, 2012; Conway, Shakeel, \& Atallah, 2011; Palmer, 1984). The importance of neighborhood age on urban forest stand density, species composition and structure has been well demonstrated. Lowry, Baker, and Ramsey (2012) found that among several physical factors, neighborhood age was the most influential factor explaining tree canopy abundance. In Baltimore, Maryland the abundance of neighborhood tree canopy increased with neighborhood age to about 45-50 years, then decreased (Grove et al., 2006). This suggests that forest and housing stocks followed a parallel inverted $U$ relationship that traced periods of appreciation and depreciation. However, in desert cities the abundance and diversity of vegetation was found to decrease as neighborhoods aged (Hope et al., 2003; Martin \& Stabler, 2004). In US cities, the majority of trees and potential tree planting sites are in low density residential land uses, so their age-related stand structure and dynamics are especially important (McPherson \& Rowntree, 1993).

\subsection{Purpose and terms defined}

This study extends research cited above by incorporating age-related differences that influence species composition, stand structure and $C$ storage in low density residential areas. The derivation and application of transfer functions is demonstrated for urban forests in Los Angeles and Sacramento, California. Relations between differences in transfer functions and causal factors such 
as species composition, basal area and tree densities are discussed. Sources of error and uncertainty are estimated, and the relevance of this approach for California's emerging cap and trade market is discussed.

Terms used in this study are defined as follows:

Carbon storage: $\mathrm{C}$ accumulated in the aboveground and belowground biomass of trees over many years (excludes $C$ stored in the soil).

Carbon sequestration: change in $\mathrm{C}$ storage in aboveground and belowground biomass that result from tree growth during a single growing season.

Avoided carbon emissions: C equivalent emission reductions from electricity generation and natural gas combustion from urban forest effects on annual building energy use for space heating and cooling.

Carbon density: $\mathrm{C}$ values divided by respective total land areas. Because the area of each region differs, comparisons between cities and land uses are made based on $C$ density values for storage $\left(\mathrm{tha}^{-1}\right)$, sequestration ( $\left.\mathrm{tha}^{-1} \mathrm{yr}^{-1}\right)$ and avoided emissions $\left(\mathrm{tha}^{-1} \mathrm{yr}^{-1}\right)$.

UTC density: $\mathrm{C}$ values divided by respective total UTC areas. These transfer functions are rendered comparable in terms of UTC C density values for storage ( $t \mathrm{ha}^{-1} \mathrm{UTC}$ ), sequestration ( $\mathrm{tha}^{-1} \mathrm{UTC}_{\mathrm{yr}}{ }^{-1}$ ) and avoided emissions ( $\mathrm{t} \mathrm{ha} \mathrm{C}^{-1} \mathrm{UTC}_{\mathrm{yr}}^{-1}$ ).

\section{Methods}

\subsection{Study areas}

The two study areas cover $1022 \mathrm{~km}^{2}$ in the City of Los Angeles, CA and $1732 \mathrm{~km}^{2}$ in the Sacramento, CA metropolitan area (Fig. 1). The City of Los Angeles (latitude: $34^{\circ} 06^{\prime} 36^{\prime \prime} \mathrm{N}$, longitude: $118^{\circ} 24^{\prime} 40^{\prime \prime} \mathrm{W}$ ) lies within one of the largest metropolitan areas in the United States and has a land area of $1225 \mathrm{~km}^{2}$. The city's population is 3.8 million and there are 15 council districts and 86 neighborhood councils. Topographic gradients are small in the coastal areas and inland valleys; however, within the city limits there are mountain ranges with steep slopes. The Santa Monica Mountains National Recreation Area and the Verdugo Mountains are examples of natural areas excluded from our analysis. Elevation changes from sea level to $1543 \mathrm{~m}$ at Mount Lukens in the northeast corner of the city. Los Angeles has beach, wetland and mountain habitats. The coastal sage scrub is still evident in protected areas, and coastal live oak (Quercus agrifolia) occurs in riparian forest communities.

The City of Sacramento (latitude: $38^{\circ} 34^{\prime} 54^{\prime \prime}$ N, longitude: $121^{\circ} 29^{\prime} 35^{\prime \prime} \mathrm{W}$ ) is the state capital of California and economic and cultural hub of the region. The Sacramento metropolitan study area included six counties and had a population of about 2.5 million. The study area excluded nonurban areas on the edge of development, such as parcels greater than 0.4 ha zoned for low density residential use. Natural areas within city boundaries and transportation corridors connecting cities were included in the study area. Small Sierra Nevada foothill communities, such as Auburn and Placerville, and Central Valley farmland communities, such as Woodland and Davis were part of the study area. The foothills are undulating to hilly, and they slope down from elevations of $250 \mathrm{~m}$ to nearly sea level at the Sacramento River. They are characterized by sparse to dense stands of blue oak (Quercus douglasii) with interior live oak (Quercus wislizenii) and foothill pine (Pinus sabiniana) interspersed. Riparian forests extend along river courses and associated bottom lands.

The climates of both Los Angeles and Sacramento are Mediterranean, characterized by hot, dry summers and cool, rainy winters from October through April. Average annual rainfall is $345 \mathrm{~mm}$ and $465 \mathrm{~mm}$ in Los Angeles and Sacramento, respectively. The Pacific Ocean moderates temperatures in Los Angeles. The average annual and lowest temperatures recorded are 19 and $-4^{\circ} \mathrm{C}$ in Los Angeles and 16 and $-8{ }^{\circ} \mathrm{C}$ in Sacramento. Los Angeles has a variety of climate zones because of its proximity to the Pacific Ocean and nearby mountain ranges. Portions of Los Angeles fell into two of the sixteen US climate zones designated by i-Tree Streets for benefit calculation. Two council districts were in the Coastal Southern California climate zone and the remaining 13 were in Inland Empire zone, hereafter referred to as coastal and inland zones (McPherson, Simpson, Xiao, \& Wu, 2011).

\subsection{Tree surveys}

Circular plots, each 0.04 ha in size, were randomly located and surveyed following UFORE protocols (Nowak et al., 2008). In Los Angeles, 370 plots were measured by a US Forest Service forester and UC Riverside graduate student during 2007 and 2008, with information recorded for 696 trees. Twenty-one of these plots were excluded from this analysis because they fell in non-urbanized areas. In Sacramento, 300 plots were measured by volunteers trained by the Sacramento Tree Foundation (STF) during 2007 and data recorded on 640 trees. Field data were obtained from STF and UC Riverside personnel after internal quality control was conducted. As recipients of the processed data, we did not influence the internal quality control measures used to prevent, identify and correct measurement (i.e., misidentification of species, tree height measurement), sampling (i.e., selection bias, omission of data fields for energy calculations) and data processing errors.

Center points for each plot were located using Google Map images. All live trees with a diameter at breast height (dbh) that exceeded $2.54 \mathrm{~cm}$ were measured with a tape to the closest $0.1 \mathrm{~cm}$. Tree height was measured with a clinometer to the closest $0.1 \mathrm{~m}$. In Sacramento, ocular estimation and plot mapping were used to calculate the percentages of plot area in tree cover, shrub cover under tree cover and shrub cover extending beyond tree cover. In Los Angeles, the percentage of shrub cover extending beyond tree cover was not recorded directly. It was calculated as the difference between total shrub cover and shrub cover under tree cover. Percentages of shrub cover not under tree cover were used later to derive urban tree cover from remotely sensed tree plus shrub cover.

\subsection{Biomass and carbon calculations}

To calculate biomass and $C$ stored in each tree sampled, species name and measured dbh were entered into the CUFR Tree Carbon Calculator (CTCC) (McPherson, Simpson, Marconett, Peper, \& Aguaron, 2008). The CTCC, a free Excel spreadsheet application, was produced by US Forest Service researchers. It uses information on climate zone, species, and size to calculate $\mathrm{C}$ stored, sequestered and avoided emissions.

The CTCC used 26 species-specific equations for trees growing in open, urban conditions. Urban-based biomass equations were developed from street and park trees measured in California (Pillsbury, Reimer, \& Thompson, 1998) and Colorado cities (Lefsky \& McHale, 2008). The rationale for nearly exclusive use of these equations is that trees in open-grown conditions partition carbon differently than closely spaced trees in forest stands because they do not compete as directly with other trees. There is evidence that they partition relatively more carbon in branches and foliage, and less carbon to the bole compared to forest trees (Brack \& Richards, 2002). Also, urban tree growth can be enhanced by periodic irrigation and care, as well as elevated levels of carbon 


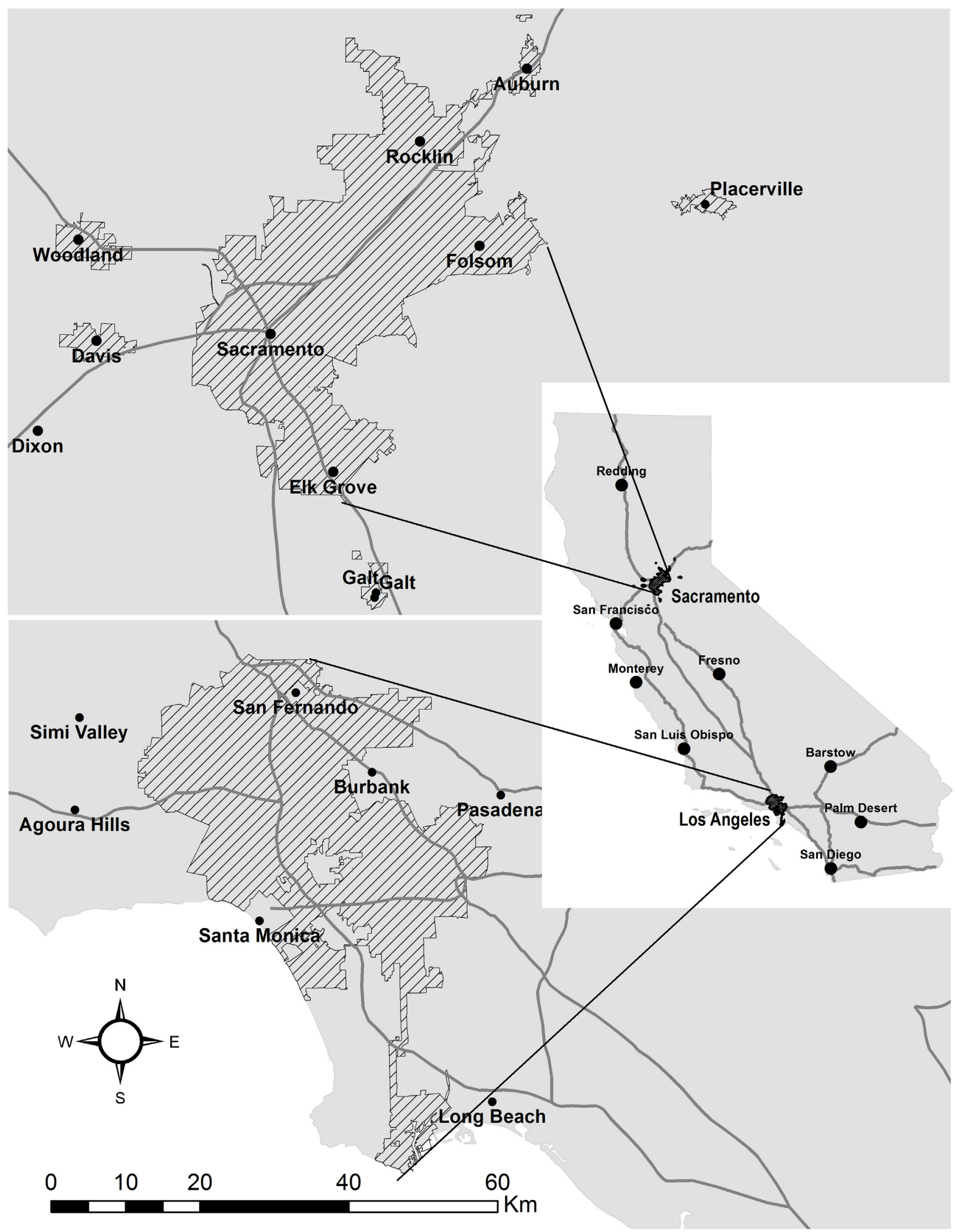

Fig. 1. The City of Los Angeles (above) and Sacramento region (below) study areas (hatched). 
and nitrogen deposition (Jo \& McPherson, 1995; Nowak \& Crane, 2002b).

The two types of allometric biomass equations used in the CTCC yielded aboveground volume and dry weight of a tree. The methodology to convert green volume into biomass and eventually to stored C is well established (Jenkins, Chojnacky, Heath, \& Birdsey, 2003a; Jenkins, Chojnacky, Heath, \& Birdsey, 2003b; Markwardt \& Wilson, 1935; Simpson, 1993) and entailed calculating total dry weight biomass, then carbon (C) and stored $C$ equivalents. Converting the fresh weight of green volume into dry weight required use of species specific dry weight density conversion factors. The amount of belowground biomass in roots of urban trees is not well researched. This study assumed that root biomass was 28 percent of total tree biomass (Cairns, Brown, Helmer, \& Baumgardner, 1997; Husch, Miller, \& Beers, 1982; Wenger, 1984). Wood volume (dry weight) was converted to $C$ by multiplying by the constant 0.50 (Lieth, Lieth, \& Whittaker, 1975).

The amount of $C$ sequestered in year $x$ was calculated as the amount stored in year $x+1$ minus the amount stored in year $x$. To project tree size at year $x+1$ the CTCC used growth curves developed from samples of about 700 street and park trees representing the 20-22 predominant species in each of the six California reference cities (Peper, McPherson, \& Mori, 2001a; Peper, McPherson, \& Mori, 2001b).

\subsection{Species matching}

Each tree in the sample plots was matched to one of the 20-22 species that were intensively studied in each climates zone's reference city. Correctly matching species from the sample to their corresponding reference city species insured that the appropriate allometric and growth equations were applied to calculate biomass and annual sequestration rates. Trees in Los Angeles plots were assigned to corresponding species in their climate zone's reference city (coastal or inland) by overlaying plot center coordinates on the climate zone map. Trees in the Sacramento plots were first assigned to species in the Central Valley climate zone, then to corresponding species from any of the five other California climate zones.

For non-matching species, each sampled species was classified with four descriptors (Urban Forest Ecosystems Institute, 1995-2012).

- tree type: broadleaf, conifer, palm

- life form: evergreen, deciduous

- mature tree size: large, medium, small

- growth rate: very fast, fast, medium fast, medium, slow medium, slow, very slow

The 20-22 species in each of the six California reference cities were similarly classified. Each non-match from the samples was matched with the best fitting reference city species according to the four descriptors. If several species matched, the assignment was made based on taxonomic criteria (same genus) or expert knowledge about the species' architecture.

\subsection{Calculation of avoided emissions from energy effects}

Avoided C emissions from effects of each sampled tree on building energy use were calculated with field data entered into the CTCC. To determine effects of tree shade on building energy performance, over 800 simulations were conducted for each of the six California reference cities using different combinations of tree sizes, locations, and building age classes (Simpson, 2002). The CTCC also incorporates effects of a tree on wind speed and air temperature through cooling from evapotranspiration. If a sampled tree was located within $18 \mathrm{~m}$ of a conditioned building, information on its distance and compass bearing relative to a building, building age class (which influences energy use) and types of heating and cooling equipment were collected and used as inputs to calculate annual heating and cooling energy effects. Associated power plant emissions reductions were based on the $\mathrm{C}$ emission factor in the CTCC, which was $395 \mathrm{~kg} \mathrm{CMWH}^{-1}$ (McPherson et al., 2008). In cases where a tree shaded more than one building, effects were summed. Avoided emissions were totaled for trees in each plot.

\subsection{Urban tree canopy delineation and measurement}

Urban tree canopy cover (UTC) was mapped using QuickBird satellite and aerial imagery. For Los Angeles, QuickBird data were collected from 2002 to 2005. For Sacramento, QuickBird data were collected from summer of 2006 with the exception of a small area covered by clouds that was collected from summer 2003. The QuickBird data included four multispectral bands (blue, green, red and near infrared) with 2.4-m spatial resolution and a panchromatic band with $60-\mathrm{cm}$ resolution. GIS data layers included the boundaries of the cities, neighborhood councils, council districts, census block groups, parcels, parks, streets and land uses.

A moving masks method (Xiao, Ustin, McPherson, Peper, \& Green, 1999) was used in conjunction with supervised and unsupervised classification to classify land cover types. Rural areas were masked out from the study area because their land cover, vegetation management, and topographic gradient were different from those of the urban areas. Four land cover types (i.e., tree [tree and shrub], grass [green grass and ground cover], dry grass/bare soil and impervious surface [building roof surfaces, asphalt and concrete pavement]) were mapped for Los Angeles. Seven land cover types (i.e., tree [tree and shrub], grass [irrigated grass and ground cover], water, roof, other impervious surface, bare soil, and dry vegetation [i.e., non-irrigated grass]) were mapped for Sacramento. Shrubs were treated as trees during image classification. Percentages of shrub cover not under tree cover developed from UFORE plot data were applied to derive urban tree cover (UTC) from remotely sensed tree plus shrub cover. Additional information on image processing, classification and analysis are available (McPherson et al., 2011; Xiao, Wu, Simpson, \& McPherson, 2009).

Land cover mapping accuracy assessments were based on visual interpretation of high resolution QuickBird and aerial imagery of randomly selected samples. Fifty randomly selected parcels in Los Angeles were digitized from the pan-sharpened multispectral images to assess land cover classification accuracy. A stratified random sample of 1000 points was digitized from the QuickBird images for the Sacramento study area. The pixel scale analysis compared classified land cover types with digitized types by pixel. Manually interpreted QuickBird data were used as the reference in the confusion matrix (Kohavi \& Provost, 1998; Xiao \& McPherson, 2005).

\subsection{Land uses and low density residential age classes}

Land use classes were designated for each plot in the field survey as per the UFORE protocol. Zoning classes were obtained from the City of Los Angeles and the Sacramento Area Council of Governments. Land use classes were cross-walked with zoning classes to derive four and eight land use classes for Los Angeles and Sacramento, respectively.

The age of each plot was determined from "date built" for the structure from parcel data for the address where the center of the plot fell. For plots without building dates, such as parks, golf courses and cemeteries, the date built information was collected from surrounding parcels or census block group data and averaged. Median building age of each census block group was obtained from 2000 US Census data. 
UFORE plots with trees in the low density residential land use class were grouped into six age classes. There were 139 and 93 low density residential plots with trees in Los Angeles and Sacramento, respectively. Plots were grouped to create a relatively even distribution of plot numbers, with a minimum of at least 11 plots per age class.

A land use/age class GIS data layer was created for each study area that mapped the locations of land use polygons and low density residential age classes by census block group using the median building age dataset. The maps for Los Angeles and Sacramento contained 9 and 13 land use/age classes, respectively.

\subsection{Transfer functions}

A C transfer function ( $J$ ), or UTC density ( $\mathrm{tCha}^{-1} \mathrm{UTC}$ ) was calculated for each land use/age class $(k)$ by dividing the $C$ totals for all trees in each plot $(i)$ by the total UTC above each plot as recorded in the field, where

$J_{k}=\frac{\sum_{i} \mathrm{C}^{(i, k)}}{\sum_{i} \mathrm{UTC}^{(i, k)}}$

Transfer functions were calculated for $\mathrm{C}$ stored, sequestered and avoided emissions for each of the land use/age classes in Los Angeles and Sacramento.

\subsection{Comparative analysis}

The total amounts of $\mathrm{C}$ stored, sequestered and emissions avoided for each study area were compared using three approaches. The field plot only approach inferred from the randomly sampled plots to the study area using the ratio of total plot area (PA) to total study area (SA).

Total $\mathrm{C}=\frac{\mathrm{SA}}{\mathrm{PA}} \times\left(\sum_{k} \sum_{i} \mathrm{C}^{(i, k)}\right)$

The single transfer function approach calculated one transfer function independent of land use that was applied to overall UTC delineated from the imagery.

Total $\mathrm{C}=\frac{\sum_{k} \sum_{i} \mathrm{C}^{(i, k)}}{\sum_{k} \sum_{i} \mathrm{UTC}^{(i, k)}} \times$ Total UTC

The multiple transfer function approach applied the transfer function calculated for each land use/age class $\left(J_{k}\right)$ to the total UTC delineated from the imagery for that land use/age class and summed the results. This approach refines the single transfer function approach by incorporating land use/age class dependent transfer functions that reflect differences in species composition and stand structure.

Total C $=\sum_{k} J_{k} \times$ Total $\mathrm{UTC}^{(k)}$

\section{Results}

\subsection{Urban tree canopy}

Overall classification accuracy for Los Angeles was 88.6 percent based on a pixel by pixel comparison. The accuracy for classifying existing UTC was 74.3 percent. Not surprisingly, TCC was most often misclassified as irrigated grass (13 percent), and vice versa (17 percent). Factors that affected the mapping accuracy included the treatment of the shadowed area and minimum mapping units during digitizing. For the Sacramento study area, there was 90 percent agreement between direct interpretation of the QuickBird

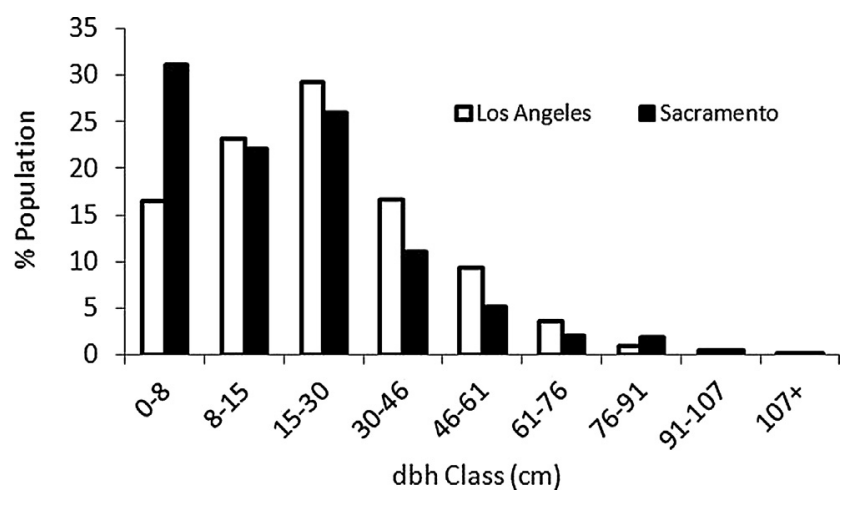

Fig. 2. Distribution of trees among dbh classes.

image and computer classification. Classification accuracy for UTC was 84 percent, with 14 percent of UTC mistakenly classified as irrigated grass. This slightly higher overall mapping accuracy is partially explained by more complete masking of cloudy areas in the Sacramento QuickBird data.

Urban tree canopy (UTC) percentages averaged 13.8 and 18.2 percent in Los Angeles and Sacramento, displaying variability among land use classes (Table 1). In Los Angeles, UTC covered 21.9 percent of low density residential (LDR) land, but only 8.0 percent of med-high density residential (HDR) land. In Sacramento, UTC covered 23 percent of both residential classes. Open space and park lands (OSP) were much more heavily forested in Sacramento than Los Angeles. Commercial/industrial (CI) land uses supported the least UTC in both cities (7-8 percent).

\subsection{Urban forest structure}

The Los Angeles study area contained approximately 4.9 million trees, about 1.1 million less than reported when non-urban plots were included (Nowak, Hoehn, Crane, Weller, \& Davila, 2011). Sacramento's urban forest contained 6.9 million trees. In both cities, the majority of all trees were in LDR land use classes (Table 2). Combined with trees in HDR areas, residential trees accounted for 71 and 67 percent of all trees in Los Angeles and Sacramento, respectively. Mean tree density was greater in Los Angeles than Sacramento ( 49.1 vs. $39.8 \mathrm{ha}^{-1}$ ), but the number of trees per capita was greater in Sacramento (2.8) than Los Angeles (1.3). These differences are partially explained by Los Angeles' higher population density ( $37 \mathrm{vs.} 14 \mathrm{ha}^{-1}$ ) and greater surface imperviousness, which constrain tree planting.

Tree densities were greatest in LDR land use (71 and $69 \mathrm{ha}^{-1}$ ) (Table 2). In Los Angeles, trees in LDR areas had the largest average dbh $(26.8 \mathrm{~cm})$, while those in Open Space/Public (OSP) had the smallest $(18.0 \mathrm{~cm})$. On average, trees in Sacramento OSP and Transportation uses were smallest $(14.1 \mathrm{~cm} \mathrm{dbh})$, while trees in Agriculture lands were the largest (33.5). The average dbh for all trees was 24.4 and $19.8 \mathrm{~cm}$ in Los Angeles and Sacramento, respectively. Over 30 percent of Sacramento's population was comprised of small trees less than $8 \mathrm{~cm}$ dbh (Fig. 2). Los Angeles' population had about one-half this proportion of small trees, and relatively higher percentages of trees between 15 and $60 \mathrm{~cm} \mathrm{dbh}$.

The most abundant tree species in Los Angeles was Italian cypress (Cupressus sempervirens), accounting for 8 percent of all trees. Native valley and interior live oak (Quercus lobata and wislizenii) were most abundant in Sacramento, together accounting for 17 percent of the population.

Relative basal area, defined as the percentage of total basal area (cross sectional area of tree trunks), is an indicator of species dominance in terms of biomass. The top ten taxa accounted for 50.6 and 38.4 percent of total basal area in Los Angeles and Sacramento, 
Table 1

Distributions of area (ha) and cover types (\%) by land use.

\begin{tabular}{|c|c|c|c|c|c|}
\hline & Area & Tree & Shrub & Grass & Impervious \\
\hline \multicolumn{6}{|l|}{ Los Angeles } \\
\hline Comm/lnd & 18,552 & 3.5 & 0.9 & 4.6 & 91.0 \\
\hline Med-Hi density res. & 17,734 & 8.0 & 6.5 & 14.3 & 71.2 \\
\hline Open space/PL & 17,250 & 8.1 & 9.5 & 23.1 & 59.3 \\
\hline Low density res. & 48,644 & 21.9 & 8.5 & 22.3 & 47.2 \\
\hline Total & 102,180 & 13.8 & 7.0 & 17.8 & 61.4 \\
\hline \multicolumn{6}{|l|}{ Sacramento } \\
\hline Comm/lnd & 29,538 & 8.0 & 2.4 & 11.5 & 78.1 \\
\hline Med-Hi density res. & 5555 & 23.3 & 3.3 & 16.8 & 56.6 \\
\hline Low density res. & 63,746 & 23.2 & 5.1 & 23.1 & 48.6 \\
\hline Agriculture & 17,190 & 23.8 & 0.2 & 39.7 & 36.3 \\
\hline Urban reserve & 12,049 & 11.4 & 1.6 & 33.2 & 53.8 \\
\hline Institutional & 11,727 & 11.8 & 3.3 & 29.2 & 55.7 \\
\hline Open space/PL & 16,266 & 28.1 & 1.8 & 36.5 & 33.6 \\
\hline Transportation & 17,170 & 9.9 & 0.8 & 16.5 & 72.8 \\
\hline Total & 173,241 & 18.2 & 3.0 & 24.3 & 54.5 \\
\hline
\end{tabular}

respectively (Fig. 3). In Los Angeles, ash (Fraxinus uhdei and velutina) and pines (Pinus spp.) were dominant, whereas three native oak species together accounted for 30 percent of total basal area in Sacramento.

\subsection{Transfer functions}

Transfer functions were calculated for each land use/age class. The number of plots with trees varied among classes, with relatively more plots in older LDR areas in Los Angeles and the post-1980 age classes in Sacramento (Table 3). Transfer functions were highly variable among land use and age classes in both cities. Storage rates in Los Angeles averaged $59 \mathrm{t} \mathrm{ha}^{-1}$ UTC across all land uses and $67.5 \mathrm{t} \mathrm{ha}^{-1}$ UTC across all LDR age classes. Storage was greatest for the 1950-1959 LDR age class (104t). In Sacramento, storage averaged $84.5 \mathrm{tha}^{-1}$ UTC across all land uses and $92.8 \mathrm{tha}^{-1}$ UTC across all LDR age classes. Storage in Sacramento was greatest in the pre1950 LDR age class (136 t ha ${ }^{-1}$ UTC) and least in the 1990-1999 LDR age class ( $27 \mathrm{t} \mathrm{ha}^{-1}$ UTC).

Transfer function values for annual sequestration followed the general patterns for storage, with the overall value for Sacramento (4.96 tha ${ }^{-1} \mathrm{UTC}^{-1}{ }^{-1}$ ) being greater than for Los Angeles $\left(3.25 \mathrm{tha}^{-1} \mathrm{UTC}_{\mathrm{yr}}^{-1}\right)$. The highest values were found in LDR land uses. In Los Angeles, the highest sequestration value was $5.1 \mathrm{tha}^{-1} \mathrm{UTC}_{\mathrm{yr}}{ }^{-1}$ in the $1970-1979$ LDR age class. The highest value in Sacramento was $6.81 \mathrm{tha}^{-1} \mathrm{UTC} \mathrm{yr}^{-1}$ in LDR 2000-10, and the lowest values were 3.37 and 3.19 t ha $^{-1} \mathrm{UTC}_{\mathrm{yr}}{ }^{-1}$ for Commercial/Industrial (CI) and LDR 2000-10, respectively.

Not surprisingly, transfer functions for annual avoided C emissions from effects of trees on building energy performance were greatest in residential land uses. However, the overall avoided emissions value was greater for Los Angeles ( $2.77 \mathrm{tha}^{-1} \mathrm{UTC} \mathrm{yr}^{-1}$ ) than Sacramento $\left(2.72 \mathrm{tha}^{-1} \mathrm{UTC}_{\mathrm{yr}}{ }^{-1}\right)$. This finding is surprising given that Sacramento's $C$ storage density and sequestration values were greater than Los Angeles'. The discrepancy can be partially explained by substantially higher tree and human densities in Los Angeles, which resulted in greater proximity between buildings and trees. In Los Angeles, 14 percent of all trees surveyed shaded more than one building, while in Sacramento only 2 percent shaded multiple buildings. This finding illustrates that care must be taken when drawing inferences from one city to another about storage, sequestration and avoided emission rates.

\subsection{Comparison of results by method}

After applying the transfer functions to UTC by land use/age class, estimates for total $\mathrm{C}$ stored, sequestered and avoided emissions were $877,049 \mathrm{t}, 47,337 \mathrm{t}$ and $44,890 \mathrm{t}$, respectively for Los Angeles (Multiple TFs in Table 4). In Sacramento, 2,268,104t, $158,635 t$ and $61,674 t$ were estimated to be stored, sequestered and avoided emissions, respectively.

Estimates of total $C$ storage, sequestration and avoided emissions were lowest when calculated using the field plots only

Table 2

Distributions of tree numbers, densities and sizes by land use (se = standard error).

\begin{tabular}{|c|c|c|c|c|c|c|}
\hline & \multicolumn{2}{|c|}{ Numbers } & \multicolumn{2}{|l|}{ Density } & \multirow{2}{*}{$\begin{array}{l}\text { Avg. } \\
\mathrm{cm}\end{array}$} & \multirow{2}{*}{$\begin{array}{l}\text { dbh } \\
\text { se }\end{array}$} \\
\hline & $\%$ Total & se & trees/ha & se & & \\
\hline \multicolumn{7}{|l|}{ Los Angeles } \\
\hline Comm/lnd & 13.0 & 1.1 & 47.3 & 18.3 & 19.9 & 1.5 \\
\hline Med-Hi density res. & 4.8 & 0.5 & 35.5 & 10.7 & 23.1 & 2.2 \\
\hline Open space/PL & 15.7 & 1.4 & 22.8 & 6.6 & 18.0 & 1.6 \\
\hline Low density res. & 66.5 & 4.6 & 70.8 & 7.3 & 26.8 & 1.0 \\
\hline Total & 100.0 & & 49.1 & 4.8 & 24.4 & \\
\hline \multicolumn{7}{|l|}{ Sacramento } \\
\hline Comm/lnd & 11.0 & 18.8 & 25.6 & 5.4 & 19.6 & 3.1 \\
\hline Med-Hi density res. & 3.1 & 37.8 & 37.9 & 14.0 & 22.8 & 4.7 \\
\hline Low density res. & 63.7 & 9.6 & 68.8 & 7.8 & 20.0 & 1.1 \\
\hline Agriculture & 3.7 & 52.8 & 14.8 & 11.3 & 33.5 & 8.7 \\
\hline Urban reserve & 5.3 & 46.7 & 30.5 & 14.0 & 27.4 & 5.2 \\
\hline Institutional & 3.2 & 36.2 & 19.0 & 19.2 & 21.6 & 5.9 \\
\hline Open space/PL & 6.2 & 36.2 & 26.1 & 38.0 & 14.1 & 4.1 \\
\hline Transportation & 3.9 & 42.9 & 15.5 & 13.3 & 14.1 & 3.6 \\
\hline Total & 100.0 & & 39.8 & 3.9 & 19.8 & \\
\hline
\end{tabular}




\section{Los Angeles}
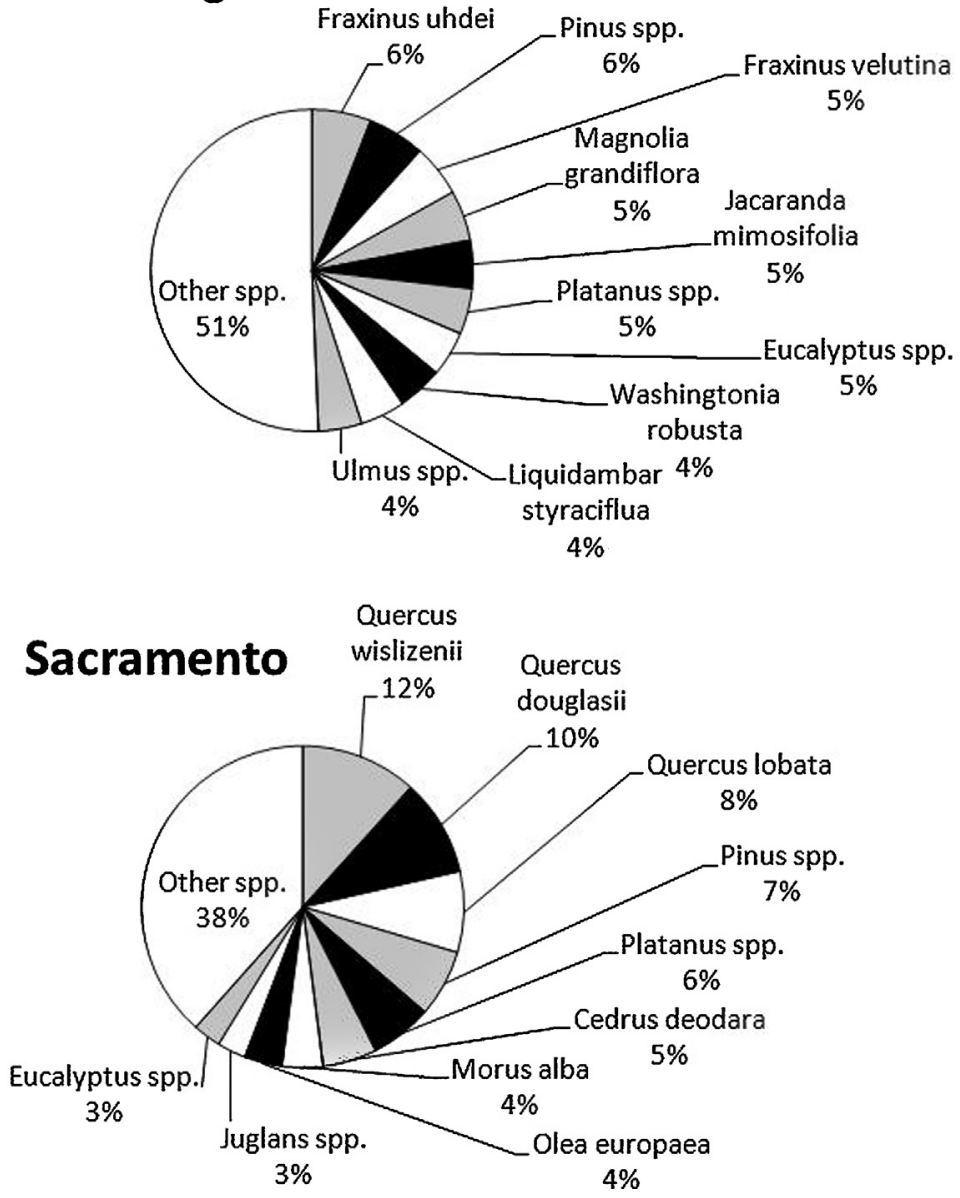

Fig. 3. Relative basal area of tree species in the Los Angeles (above) and Sacramento (below) study areas.

Table 3

Urban tree canopy (UTC) C densities by land use/age class in terms of stored ( $\mathrm{t} \mathrm{ha}^{-1} \mathrm{UTC}$ ), sequestered ( $\mathrm{tha}^{-1} \mathrm{UTC}^{\mathrm{yr}} \mathrm{r}^{-1}$ ) and avoided emissions ( $\mathrm{t}$ ha ${ }^{-1} \mathrm{UTC} \mathrm{yr} \mathrm{r}^{-1}$ ).

\begin{tabular}{|c|c|c|c|c|c|c|c|}
\hline & No. plots & Stored & se & Sequestered & se & Avoided & se \\
\hline \multicolumn{8}{|l|}{ Los Angeles } \\
\hline Comm/lnd & 20 & 38.7 & 14.47 & 3.44 & 1.29 & 3.62 & 2.15 \\
\hline Med-Hi density res. & 11 & 43.0 & 14.54 & 3.23 & 1.57 & 5.98 & 2.38 \\
\hline Open space/PL & 31 & 38.0 & 13.19 & 2.58 & 0.80 & 0.47 & 0.30 \\
\hline LDR pre-1940s & 33 & 67.2 & 19.48 & 2.30 & 0.63 & 3.39 & 0.94 \\
\hline LDR 1940-1949 & 21 & 49.8 & 13.78 & 2.72 & 0.75 & 2.56 & 0.89 \\
\hline LDR 1950-1959 & 42 & 104.2 & 31.84 & 4.74 & 1.07 & 4.47 & 1.19 \\
\hline LDR 1960-1969 & 17 & 35.3 & 11.02 & 2.69 & 1.08 & 1.59 & 0.58 \\
\hline LDR 1970-1979 & 14 & 66.0 & 22.39 & 5.10 & 1.89 & 3.18 & 1.10 \\
\hline LDR $1980-2010$ & 12 & 40.1 & 13.36 & 2.66 & 1.09 & 0.48 & 0.24 \\
\hline All LDR & 139 & 67.5 & 10.39 & 3.38 & 0.42 & 3.03 & 0.44 \\
\hline All land uses/ages & & 59.0 & 7.77 & 3.25 & 0.35 & 2.77 & 0.38 \\
\hline \multicolumn{8}{|l|}{ Sacramento } \\
\hline Comm/lnd & 23 & 42.2 & 19.50 & 3.37 & 1.06 & 1.66 & 1.02 \\
\hline Med-Hi density res. & 5 & 43.7 & 19.20 & 3.64 & 1.50 & 1.13 & 0.81 \\
\hline Agriculture & 5 & 77.5 & 50.45 & 5.56 & 3.83 & 0.00 & 0.00 \\
\hline Urban reserve & 7 & 112.2 & 39.61 & 5.40 & 2.45 & 0.00 & 0.00 \\
\hline Institutional & 8 & 121.1 & 93.49 & 6.79 & 3.91 & 2.70 & 1.18 \\
\hline Open space/PL & 15 & 75.6 & 50.45 & 5.84 & 3.33 & 0.00 & 0.00 \\
\hline Transportation & 5 & 59.3 & 44.53 & 4.86 & 2.69 & 0.00 & 0.00 \\
\hline LDR pre-1950s & 11 & 135.6 & 56.30 & 4.28 & 1.30 & 2.33 & 1.47 \\
\hline LDR 1950-1969 & 20 & 72.1 & 13.35 & 5.84 & 1.77 & 4.66 & 0.86 \\
\hline LDR 1970-1979 & 16 & 61.2 & 22.58 & 4.23 & 1.61 & 2.50 & 0.96 \\
\hline LDR 1980-1989 & 14 & 98.9 & 63.58 & 5.55 & 2.91 & 2.09 & 0.93 \\
\hline LDR 1990-1999 & 18 & 26.8 & 10.05 & 3.19 & 1.02 & 5.26 & 2.00 \\
\hline LDR 2000-2010 & 14 & 71.3 & 55.50 & 6.81 & 3.69 & 13.89 & 6.09 \\
\hline All LDR & 93 & 92.8 & 21.02 & 5.11 & 0.82 & 4.11 & 0.67 \\
\hline All land uses/ages & & 84.5 & 14.40 & 4.96 & 0.62 & 2.72 & 0.42 \\
\hline
\end{tabular}


Table 4

Estimates of $\mathrm{C}$ stored $(\mathrm{t})$, sequestered $\left(\mathrm{t} \mathrm{yr}^{-1}\right)$ and avoided $\mathrm{C}$ emissions $\left(\mathrm{t} \mathrm{yr}^{-1}\right)$ for each study area obtained with three approaches.

\begin{tabular}{|c|c|c|c|c|c|c|}
\hline & Stored & se & Sequestered & se & Avoided & se \\
\hline \multicolumn{7}{|l|}{ Los Angeles } \\
\hline Field plots only & 803,413 & 95,343 & 44,279 & 4040 & 37,688 & 4776 \\
\hline Single Trans. Func. & 832,760 & 98,826 & 45,896 & 4188 & 39,065 & 4951 \\
\hline Multiple TFs & 877,049 & 137,775 & 47,337 & 5900 & 44,890 & 6895 \\
\hline \multicolumn{7}{|l|}{ Sacramento } \\
\hline Field plots only & $2,236,186$ & 349,815 & 131,286 & 13,889 & 71,945 & 9855 \\
\hline Single Trans. Func. & $2,667,431$ & 417,277 & 156,604 & 16,568 & 85,819 & 11,756 \\
\hline MultioleTFs & $2,268,104$ & 405,519 & 158,635 & 27,072 & 61,674 & 8457 \\
\hline
\end{tabular}

approach except for avoided emissions in Sacramento (Table 4). In Los Angeles, applying the single and multiple transfer functions produced estimates 4-19 percent greater than the plot only approach, respectively. In Sacramento, estimates calculated with the transfer function approach were 1-21 percent greater except for avoided emissions, which was 14 percent less than the plotbased estimate.

\subsection{Carbon stored, sequestered and avoided emissions densities}

Carbon density values varied by land use (Table 5 ). Storage densities ranged from $1.34(\mathrm{CI})$ to 14.82 (LDR) tha ${ }^{-1}$ in Los Angeles and 3.39 (CI) to $21.51 \mathrm{tha}^{-1}$ (LDR) in Sacramento. The overall average storage density in Sacramento $\left(15.40 \mathrm{tha}^{-1}\right.$ ) was about twice the amount in Los Angeles (8.15 $\left.\mathrm{tha}^{-1}\right)$.

The overall average annual sequestration density value was greater in Sacramento $\left(0.90 \mathrm{tha}^{-1} \mathrm{yr}^{-1}\right)$ than Los Angeles $\left(0.45 \mathrm{tha}^{-1} \mathrm{yr}^{-1}\right)$. Sequestration densities were lowest in CI land uses and relatively high in LDR uses. In Sacramento, the highest sequestration densities were in OS/PL and Agriculture. Los Angeles' and Sacramento's overall average annual avoided $C$ emission densities were 0.38 and $0.50 \mathrm{tha}^{-1} \mathrm{yr}^{-1}$, respectively. Avoided C emissions densities were greatest in LDR land uses where trees had the greatest effects on building energy performance.

\section{Discussion}

\subsection{Comparison between Los Angeles and Sacramento}

Differences in the amounts of $\mathrm{C}$ stored, sequestered and avoided emissions by the urban forests of Los Angeles and Sacramento illustrate the complex influence of regional and local determinants. For example, average tree density ( $49 \mathrm{vs} .40 \mathrm{ha}^{-1}$ ) and size (24.4 vs. $19.8 \mathrm{~cm}$ dbh) was greater in Los Angeles, but mean C storage density was 53 percent of Sacramento's. On average, Sacramento's trees stored (329 vs. $178 \mathrm{~kg}$ per tree) and sequestered (23.0 vs. $9.6 \mathrm{~kg}$ per tree annually) nearly twice the amount of carbon as Los Angeles'. These anomalies can be partially explained by differences in species composition and the extent to which natural areas are included in the study areas.

Differences in species composition reflect each region's distinctive climate and horticultural preferences. These differences influence $C$ storage, which is a product of species-specific biomass equations and wood density values. Wood density values can vary threefold by species, from lows of about $300 \mathrm{~kg} \mathrm{~m}^{-3}$ to highs of $900 \mathrm{~kg} \mathrm{~m}^{-3}$. In Los Angeles, ash (F. uhdei and velutina) comprised 11 percent of total basal area, with relatively high wood density (600$700 \mathrm{~kg} \mathrm{~m}^{-3}$ ). However, the next most dominant taxa (i.e., pines, southern magnolia, jacaranda and plane) had relatively low wood densities (350-550 $\mathrm{kg} \mathrm{m}^{-3}$ ). In Sacramento, native oaks (Q. lobata, wislezenii, douglasii) had very high wood densities $\left(815 \mathrm{~kg} \mathrm{~m}^{-3}\right)$ and accounted for 30 percent of the population's total basal area. Other dominant species, such as mulberry (Morus alba) and olive
(Olea europaea) had high wood density values. Hence, differences in $C$ storage between cities are better explained by measures of dominance and species-specific wood density than by average values of tree density and size.

Natural reserves, mountains and other large natural areas were excluded from the Los Angeles study area, but the Sacramento study area included suburban and exurban development. In Los Angeles, 80 percent of the stored $C$ was in LDR and only 11 percent in OS/PL. In Sacramento, 63 percent was in LDR and 20 percent in $\mathrm{OS} / \mathrm{PL}, \mathrm{AGR}$ and UR. Inclusion of agricultural lands with larger than average size trees, and natural areas that included riparian forests and oak woodlands, may partially explain higher C storage levels in Sacramento despite overall lower tree density. Raciti, Hutyra, Rao, and Finzi (2012) found that inconsistent definitions of "urban" land use were partially responsible for conflicting conclusions regarding the importance of urban soils and vegetation as C sinks. One limitation of this study is inconsistent study area boundaries that cloud comparisons between the two cities.

\subsection{Comparison with other studies}

Carbon storage reported here $(2.3$ million $\mathrm{t})$ is similar to the amount reported previously for Sacramento County (2.2 million $\mathrm{t}$ ) (McPherson, 1998). The results are difficult to compare directly because 76 percent of the Sacramento County study area was Rural Sector with low average UTC (5\%). Urban tree canopy for the Suburban Sector (15\%) was closest to the 18.2 percent reported here. The Suburban Sector's carbon storage (15.4 vs. $11.1 \mathrm{tha}^{-1}$ ), annual sequestration ( 0.90 vs. $\left.0.70 \mathrm{tha}^{-1}\right)$ and annual avoided emission ( 0.50 vs. 0.26 t ha $\left.^{-1}\right)$ density values are lower but comparable to this study's findings. Application of the transfer functions in Los Angeles resulted in a lower estimate of $C$ storage $(0.88$ vs. 1.27 million $t$ ) than reported previously for the nearly 20 percent larger study area that included natural areas and mountains (Nowak et al., 2011). The C storage (8.2 vs. 10.4 tha $^{-1}$ ) and annual sequestration ( 0.5 vs. $\left.0.6 \mathrm{tha}^{-1}\right)$ density values are quite similar. The annual avoided emission ( 0.38 vs. $\left.0.03 \mathrm{tha}^{-1}\right)$ density value reported in this study is substantially higher, due in part to trees in natural areas having minimal effect on building energy use.

A comparison of findings for Los Angeles and Sacramento, both Mediterranean climate cities, with results for cities in Table 6 reflects the effects of regional determinants such as climate and forest biome. Most of the 32 cities are in temperate zones where forests thrive in pervious, interstitial spaces. The overall $C$ storage densities for Los Angeles (8.2 $\mathrm{tha}^{-1}$ ) and Sacramento $\left(15.4 \mathrm{tha}^{-1}\right)$ were below the mean $\left(16.1 \mathrm{tha}^{-1}\right)$ but within one standard deviation for all cities (10.9 tha $^{-1}$ ). C storage densities were comparable to other Mediterranean climate cities, such as Barcelona (11.2 $\mathrm{tha}^{-1}$ ) and San Francisco $\left(14.5 \mathrm{tha}^{-1}\right)$.

Annual carbon sequestration densities for Los Angeles (0.45 $\left.\mathrm{tha}^{-1} \mathrm{yr}^{-1}\right)$ and Sacramento (0.90 $\left.\mathrm{tha}^{-1} \mathrm{yr}^{-1}\right)$ bracketed the mean $\left(0.60 \mathrm{tha}^{-1} \mathrm{yr}^{-1}\right)$ for 32 cities. Los Angeles' value 
Table 5

Carbon densities by land use for stored $\left(\mathrm{tha}^{-1}\right)$, sequestered $\left(\mathrm{tha}^{-1} \mathrm{yr}^{-1}\right)$ and avoided emissions $\left(\mathrm{tha}^{-1} \mathrm{yr}^{-1}\right)$.

\begin{tabular}{|c|c|c|c|c|c|c|}
\hline & Stored & se & Sequestered & se & Avoided & se \\
\hline \multicolumn{7}{|l|}{ Los Angeles } \\
\hline Comm/lnd & 1.34 & 0.50 & 0.12 & 0.04 & 0.13 & 0.07 \\
\hline Med-Hi density res. & 3.42 & 1.16 & 0.26 & 0.13 & 0.48 & 0.19 \\
\hline Open space/PL & 3.07 & 1.07 & 0.21 & 0.06 & 0.04 & 0.02 \\
\hline Low density res. & 14.82 & 2.28 & 0.74 & 0.09 & 0.66 & 0.10 \\
\hline Total & 8.15 & 1.07 & 0.45 & 0.05 & 0.38 & 0.05 \\
\hline \multicolumn{7}{|l|}{ Sacramento } \\
\hline Comm/lnd & 3.39 & 1.57 & 0.27 & 0.09 & 0.13 & 0.08 \\
\hline Med-Hi density res. & 10.18 & 4.48 & 0.85 & 0.35 & 0.26 & 0.19 \\
\hline Low density res. & 21.51 & 4.87 & 1.18 & 0.19 & 0.95 & 0.16 \\
\hline Agriculture & 18.41 & 11.98 & 1.32 & 0.91 & 0.00 & 0.00 \\
\hline Urban reserve & 12.80 & 4.52 & 0.62 & 0.28 & 0.00 & 0.00 \\
\hline Institutional & 14.33 & 11.06 & 0.80 & 0.46 & 0.32 & 0.14 \\
\hline Open space/PL & 21.25 & 14.19 & 1.64 & 0.94 & 0.00 & 0.00 \\
\hline Transportation & 5.89 & 4.42 & 0.48 & 0.27 & 0.00 & 0.00 \\
\hline Total & 15.40 & 2.62 & 0.90 & 0.11 & 0.50 & 0.08 \\
\hline
\end{tabular}

was similar to Barcelona (0.54tha- $\mathrm{yr}^{-1}$ ) and San Francisco (0.38 $\left.\mathrm{tha}^{-1} \mathrm{yr}^{-1}\right)$, but Sacramento's value approached the highest previously reported (1.2 $\mathrm{tha}^{-1} \mathrm{yr}^{-1}$, Atlanta, Gainesville, Morgantown) (Table 6). Sacramento has a relatively young tree population that is actively adding biomass. Also, Sacramento's Mediterranean climate and abundant irrigation account in part for relatively more annual growth and biomass accumulation than reported for trees in temperate climate urban forests.

Annual avoided $\mathrm{C}$ emissions rates reported for Los Angeles and Sacramento (0.38 and $\left.0.50 \mathrm{tha}^{-1} \mathrm{yr}^{-1}\right)$ were higher than reported for Gainesville, FL $\left(0.37 \mathrm{tha}^{-1} \mathrm{yr}^{-1}\right)$ and Washington $\mathrm{DC}\left(0.36 \mathrm{tha}^{-1} \mathrm{yr}^{-1}\right)$ (Table 6$)$. Because the 13 city sample contains a preponderance of cities in temperate climates, where winter shade from trees can offset summer cooling savings, it is not surprising that values for these two California cities were high.

UTC storage densities for Los Angeles (59.0 tha ${ }^{-1}$ UTC) and Sacramento (84.5 tha ${ }^{-1}$ UTC) bracketed the mean ( $72.6 \mathrm{t} \mathrm{ha}^{-1}$ UTC) and fell within one standard deviation of values for the 32 cities (33.5 tha $\mathrm{t}^{-1}$ UTC). UTC storage densities were less for Barcelona (44.7 tha $^{-1}$ UTC) and greater for San Francisco (121.5 tha ${ }^{-1}$ UTC) than for Los Angeles and Sacramento.

Annual UTC sequestration rates for Los Angeles (3.25 $\left.\mathrm{tha}^{-1} \mathrm{UTC}_{\mathrm{yr}}^{-1}\right)$ and Sacramento (4.96 $\left.\mathrm{tha}^{-1} \mathrm{UTC}^{-1}\right)$

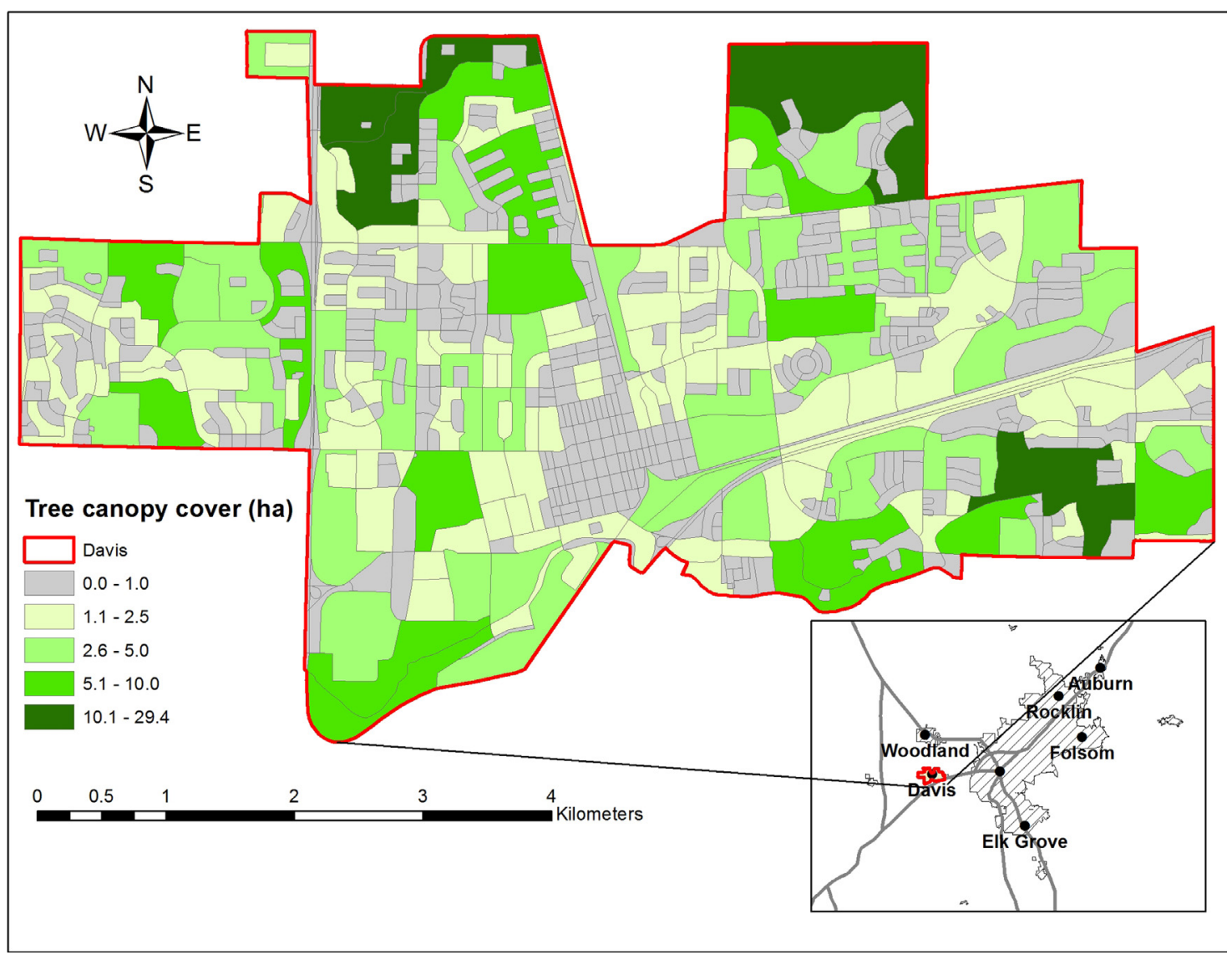

Fig. 4. Urban tree canopy classes mapped by census block group for the city of Davis, CA (Sacramento study area). 
Table 6

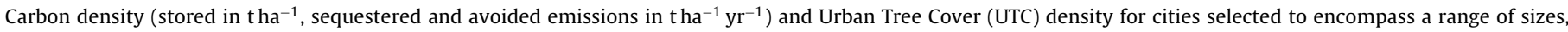
climates and cultures.

\begin{tabular}{|c|c|c|c|c|c|c|c|c|}
\hline \multirow[t]{2}{*}{ City } & \multicolumn{3}{|c|}{ Density } & \multicolumn{3}{|c|}{ UTC density } & \multirow[t]{2}{*}{ Method } & \multirow[t]{2}{*}{ Source } \\
\hline & Stored & Sequester & Avoided & Stored & Sequester & Avoided & & \\
\hline Atlanta, GA & 35.7 & 1.23 & & 97.3 & 3.36 & & $\begin{array}{l}205 \text { UFORE plots in } 1997 \text { and carbon } \\
\text { modeling }\end{array}$ & Nowak and Crane (2002b) \\
\hline Baltimore, MD & 25.9 & 0.70 & & 123.2 & 3.34 & & $\begin{array}{l}202 \text { UFORE plots in } 1999 \text { and carbon } \\
\text { modeling }\end{array}$ & Nowak and Crane (2002b) \\
\hline Barcelona, Spain & 11.2 & 0.54 & & 44.7 & 2.14 & & $\begin{array}{l}250 \text { UFORE plots in } 2009 \text { and carbon } \\
\text { modeling }\end{array}$ & Chaparro and Terradas (2009) \\
\hline Beijing, China & 7.4 & 0.38 & 0.16 & 45.3 & 2.32 & 1.01 & $\begin{array}{l}250 \text { fixed plots, stratified by tree cover } \\
\text { for three development classes }\end{array}$ & $\begin{array}{l}\text { Yang, McBride, Zhou, and Sun } \\
(2005)\end{array}$ \\
\hline Boston, MA & 20.2 & 0.67 & & 90.8 & 2.99 & & $\begin{array}{l}217 \text { UFORE plots in } 1996 \text { and carbon } \\
\text { modeling }\end{array}$ & Nowak and Crane (2002b) \\
\hline Calgary, Alberta & 5.6 & 0.27 & & 77.7 & 3.74 & & $\begin{array}{l}350 \text { UFORE plots in } 1998 \text { and carbon } \\
\text { modeling }\end{array}$ & Nowak and Crane (2002b) \\
\hline Casper, WY & 6.1 & 0.20 & -0.02 & 68.9 & 2.24 & -0.20 & $\begin{array}{l}234 \text { UFORE plots in } 2006 \text { and carbon } \\
\text { modeling }\end{array}$ & $\begin{array}{l}\text { Nowak, Hoehn, Crane, Stevens, } \\
\text { and Walton (2006a) }\end{array}$ \\
\hline Chicago, IL & 10.9 & 0.38 & -0.02 & 63.3 & 2.23 & -0.11 & 745 UFORE plots and carbon modeling & $\begin{array}{l}\text { Nowak, Hoehn, Crane, Stevens, } \\
\text { and Fisher (2010) }\end{array}$ \\
\hline Chuncheon, Korea & 1.3 & 0.15 & & 10.5 & 1.25 & & $\begin{array}{l}234 \text { variable size plots, growth rates } \\
\text { from forest and felled urban trees }\end{array}$ & Jo $(2002)$ \\
\hline Freehold, NJ & 35.8 & 0.98 & & 104.0 & 2.86 & & $\begin{array}{l}\text { About } 200 \text { UFORE plots and carbon } \\
\text { modeling }\end{array}$ & Nowak and Crane (2002b) \\
\hline Gainesville, FL & 31.9 & 1.23 & 0.37 & 60.3 & 2.32 & 0.69 & 93 UFORE plots and carbon modeling & Escobedo et al. (2010) \\
\hline Houston, TX & 18.1 & 0.74 & 0.04 & 76.4 & 3.12 & 0.16 & $\begin{array}{l}332 \text { plots in } 2001 / 2002 \text {, exurban } \\
\text { included, and carbon modeling }\end{array}$ & Nowak (2005) \\
\hline Jersey City, NJ & 5.0 & 0.21 & & 43.3 & 1.84 & & $\begin{array}{l}220 \text { UFORE plots in } 1998 \text { and carbon } \\
\text { modeling }\end{array}$ & Nowak and Crane (2002b) \\
\hline Kangleung, Korea & 1.7 & 0.19 & & 13.0 & 1.47 & & $\begin{array}{l}271 \text { variable size plots, growth rates } \\
\text { from forest and felled urban trees }\end{array}$ & Jo (2002) \\
\hline Leipzig, Germany & 11.9 & 0.00 & & 60.4 & 0.00 & & $\begin{array}{l}\text { Aboveground carbon only, } 10 \text { UFORE } \\
\text { plots in each of } 19 \text { land cover classes }\end{array}$ & Strohbach and Haase (2012) \\
\hline Miami-Dade, FL & 11.8 & 0.87 & 0.09 & 84.0 & 6.23 & 0.66 & 229 UFORE plots and carbon modeling & Escobedo et al. (2010) \\
\hline Minneapolis, MN & 15.0 & 0.53 & 0.05 & 56.8 & 2.02 & 0.20 & $\begin{array}{l}110 \text { UFORE plots in } 2005 \text { and carbon } \\
\text { modeling }\end{array}$ & $\begin{array}{l}\text { Nowak, Hoehn, Crane, Stevens, } \\
\text { and Walton (2006b) }\end{array}$ \\
\hline Moorestown, NJ & 27.9 & 0.91 & & 99.8 & 3.24 & & $\begin{array}{l}\text { About } 200 \text { UFORE plots and carbon } \\
\text { modeling }\end{array}$ & Nowak and Crane (2002b) \\
\hline Morgantown, WV & 37.8 & 1.18 & & 106.4 & 3.32 & & $\begin{array}{l}\text { About } 200 \text { UFORE plots and carbon } \\
\text { modeling }\end{array}$ & Nowak and Crane (2002b) \\
\hline NYC, NY & 15.3 & 0.48 & 0.03 & 73.3 & 2.30 & 0.13 & $\begin{array}{l}206 \text { UFORE plots in } 1996 \text { and carbon } \\
\text { modeling }\end{array}$ & $\begin{array}{l}\text { Nowak, Hoehn, Crane, Stevens, } \\
\text { and Walton (2007a) }\end{array}$ \\
\hline Oakville, Ontario & 9.6 & 0.43 & 0.02 & 33.0 & 1.48 & 0.08 & $\begin{array}{l}372 \text { UFORE plots in } 2005 \text { and carbon } \\
\text { modeling }\end{array}$ & McNeil and Vava (2006) \\
\hline Philadelphia, PA & 14.1 & 0.43 & 0.01 & 89.9 & 2.73 & 0.04 & $\begin{array}{l}210 \text { UFORE plots in } 1996 \text { and carbon } \\
\text { modeling }\end{array}$ & $\begin{array}{l}\text { Nowak, Hoehn, Crane, Stevens, } \\
\text { and Walton (2007b) }\end{array}$ \\
\hline Sacramento, CA & 8.5 & 0.25 & 0.08 & 118.9 & 3.52 & 1.12 & $\begin{array}{l}675 \text { fixed plots, random sample } \\
\text { stratified by tree cover }\end{array}$ & McPherson (1998) \\
\hline San Francisco, CA & 14.5 & 0.38 & & 121.5 & 3.19 & & $\begin{array}{l}194 \text { UFORE plots in } 2004 \text { and carbon } \\
\text { modeling }\end{array}$ & $\begin{array}{l}\text { Nowak, Hoehn, Crane, Stevens, } \\
\text { and Walton (2007c) }\end{array}$ \\
\hline Seoul-Junglang & 2.0 & 0.22 & & 15.2 & 1.69 & & $\begin{array}{l}91 \text { variable size plots, growth rates } \\
\text { from forest and felled urban trees }\end{array}$ & Jo $(2002)$ \\
\hline Seoul-Kangnam, Korea & 1.8 & 0.14 & & 13.8 & 1.11 & & $\begin{array}{l}121 \text { variable size plots, growth rates } \\
\text { from forest and felled urban trees }\end{array}$ & Jo (2002) \\
\hline Shenyang, China & 7.4 & 0.63 & & 33.3 & 2.85 & & $\begin{array}{l}\text { Stratified random sample across } 5 \\
\text { forest types, } 213 \text { variable size plots }\end{array}$ & Liu and $\mathrm{Li}$ (2012) \\
\hline Scranton, PA & 20.3 & 0.87 & 0.04 & 92.1 & 3.96 & 0.19 & $\begin{array}{l}182 \text { UFORE plots in } 2006 \text { and carbon } \\
\text { modeling }\end{array}$ & $\begin{array}{l}\text { Nowak, Hoehn, Crane, Stevens, } \\
\text { and Cotrone (2010a) }\end{array}$ \\
\hline Syracuse, NY & 24.1 & 0.75 & & 104.4 & 3.26 & & $\begin{array}{l}200 \text { UFORE plots in } 1999 \text { and carbon } \\
\text { modeling }\end{array}$ & $\begin{array}{l}\text { Nowak, Crane, and Stevens } \\
\text { (2001) }\end{array}$ \\
\hline Toronto, Canada & 17.4 & 0.73 & & 87.3 & 3.68 & & $\begin{array}{l}211 \text { UFORE plots in } 2000 \text { and carbon } \\
\text { modeling }\end{array}$ & Nowak and Crane (2002a) \\
\hline Washington, DC & 30.0 & 0.92 & 0.36 & 104.8 & 3.23 & 1.24 & $\begin{array}{l}201 \text { UFORE plots in } 2004 \text { and carbon } \\
\text { modeling }\end{array}$ & $\begin{array}{l}\text { Nowak, Hoehn, Crane, Stevens, } \\
\text { and Walton (2006c) }\end{array}$ \\
\hline Woodbridge, NJ & 24.2 & 0.85 & & 82.0 & 2.87 & & $\begin{array}{l}\text { About } 200 \text { UFORE plots and carbon } \\
\text { modeling }\end{array}$ & Nowak and Crane (2002b) \\
\hline Mean & 16.1 & 0.60 & 0.09 & 72.6 & 2.79 & 0.40 & & \\
\hline Std Dev & 10.9 & 0.33 & 0.13 & 33.5 & 1.02 & 0.48 & & \\
\hline
\end{tabular}

exceeded the mean for 32 cities (2.79 $\mathrm{tha}^{-1} \mathrm{UTC}_{\mathrm{yr}}^{-1}$, Table 6$)$, and the rates for Barcelona (2.14 $\mathrm{tha}^{-1} \mathrm{UTC} \mathrm{yr}^{-1}$ ) and San Francisco (3.19 $\left.\mathrm{tha}^{-1} \mathrm{UTC}_{\mathrm{yr}}{ }^{-1}\right)$. The rate for Sacramento was only exceeded by the rate reported for Miami-Dade (6.23 $\mathrm{tha}^{-1} \mathrm{UTC} \mathrm{yr}^{-1}$ ) (Escobedo et al., 2010).
Annual UTC avoided emissions rates for Los Angeles (2.77 $\mathrm{tha}^{-1} \mathrm{UTC}_{\mathrm{yr}}^{-1}$ ) and Sacramento (2.72 $\mathrm{tha}^{-1} \mathrm{UTC}_{\mathrm{yr}}^{-1}$ ) were about five times greater than the mean for 13 cities

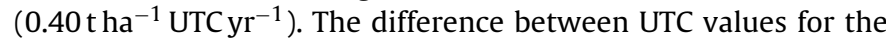
two California cities and Gainesville (0.69 tha ${ }^{-1} \mathrm{UTC}_{\mathrm{yr}}^{-1}$ ) and 


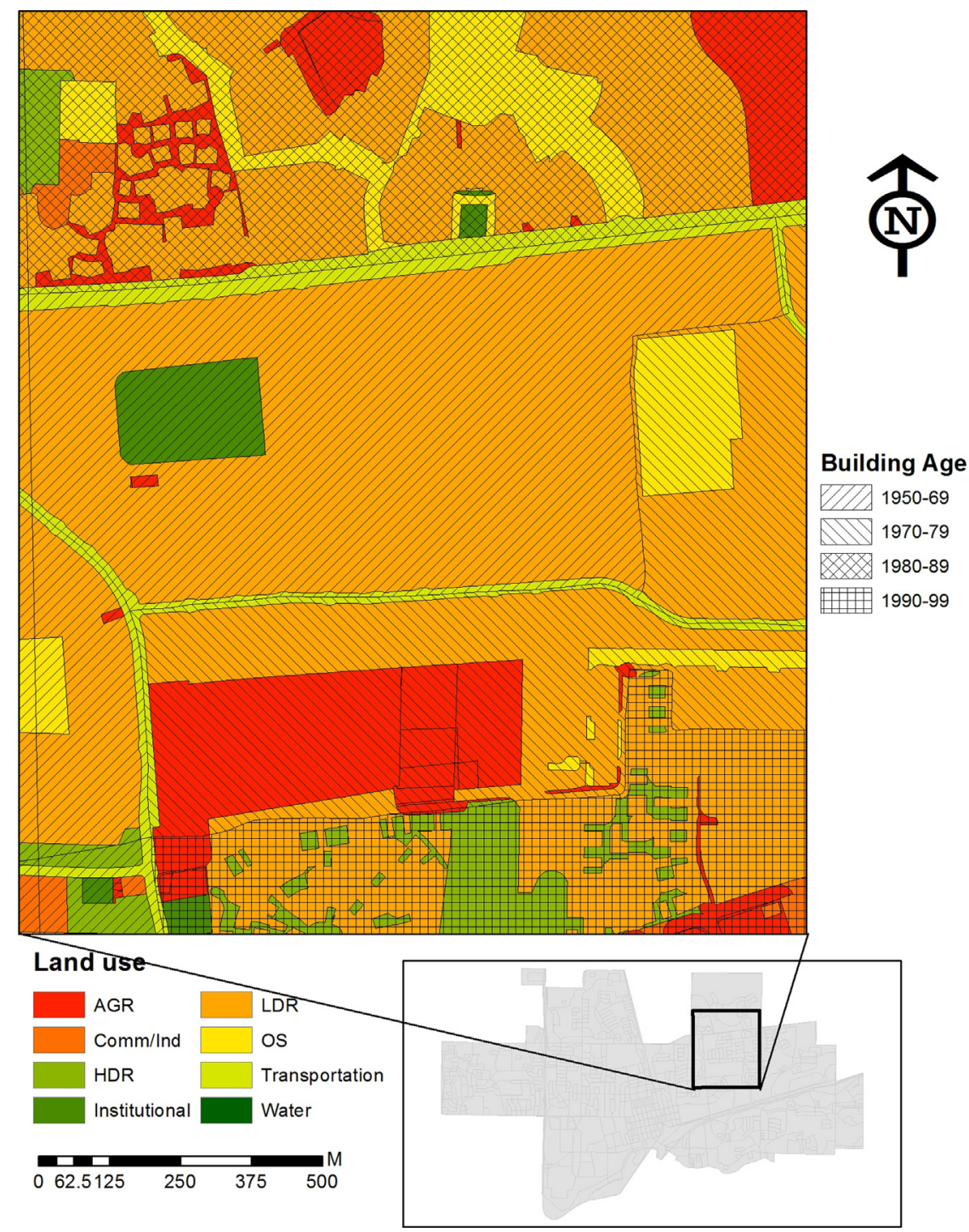

Fig. 5. Land use/age classes for a portion of Davis, CA.

Washington DC (1.24 $\mathrm{tha}^{-1} \mathrm{UTC}_{\mathrm{yr}}^{-1}$ ) may be partially due to differences in the way models account for tree growth and shading effects on building energy use (Aguaron \& McPherson, 2012). For example, it is not clear if the UFORE analyses cited above included the shading effects of a single tree on multiple buildings. In Los Angeles, 14 percent of all trees sampled shaded two or more nearby buildings, and the CTCC incorporated shade from the same tree on up to three buildings. Similarly, the models differ in treatment of shade effects from multiple trees on the same building. Although beyond the scope of this study, such differences merit further investigation because 55 percent of all trees sampled were within the $18 \mathrm{~m}$ distance considered close enough to cast shade on buildings.

\subsection{Transfer function approach}

Although C estimates calculated with the multiple transfer function approach tended to be higher than estimates from the other approaches, the differences among approaches are still relatively small. Because the differences among means are less than differences among the coefficients of variation (se/estimate), which range from 9 to 18 percent, differences among means could be due to sampling variability as opposed to any real difference.

Application of multiple transfer functions allows for mapping of C storage, sequestration and avoided emission rates at high spatial resolution. For example, UTC classes are mapped by census block group for the City of Davis, which is in the Sacramento metropolitan region (Fig. 4). Land use/age classes are mapped for a portion of Davis (Fig. 5). Carbon stored by the urban forest in each census block group was calculated as the product of each polygon's UTC and its land use/age class specific transfer function. These values were summed for all the polygons in each census block group and classified for mapping (Fig. 6). Results can be reported at a variety of scales, such as by council district, census tract or zip code. The spatial variability of $C$ stored, sequestered and avoided emissions can be readily observed at different scales.

Future research that identifies relations between $C$ and different land use/age classes across time will make it possible to model how baseline $C$ storage is likely to change as different neighborhoods age. For example, a time series analysis reconstructed the development of Los Angeles's urban forest from 1920 to 2006 and found that patterns of tree density varied with development age (Gillespie et al., 2012). 


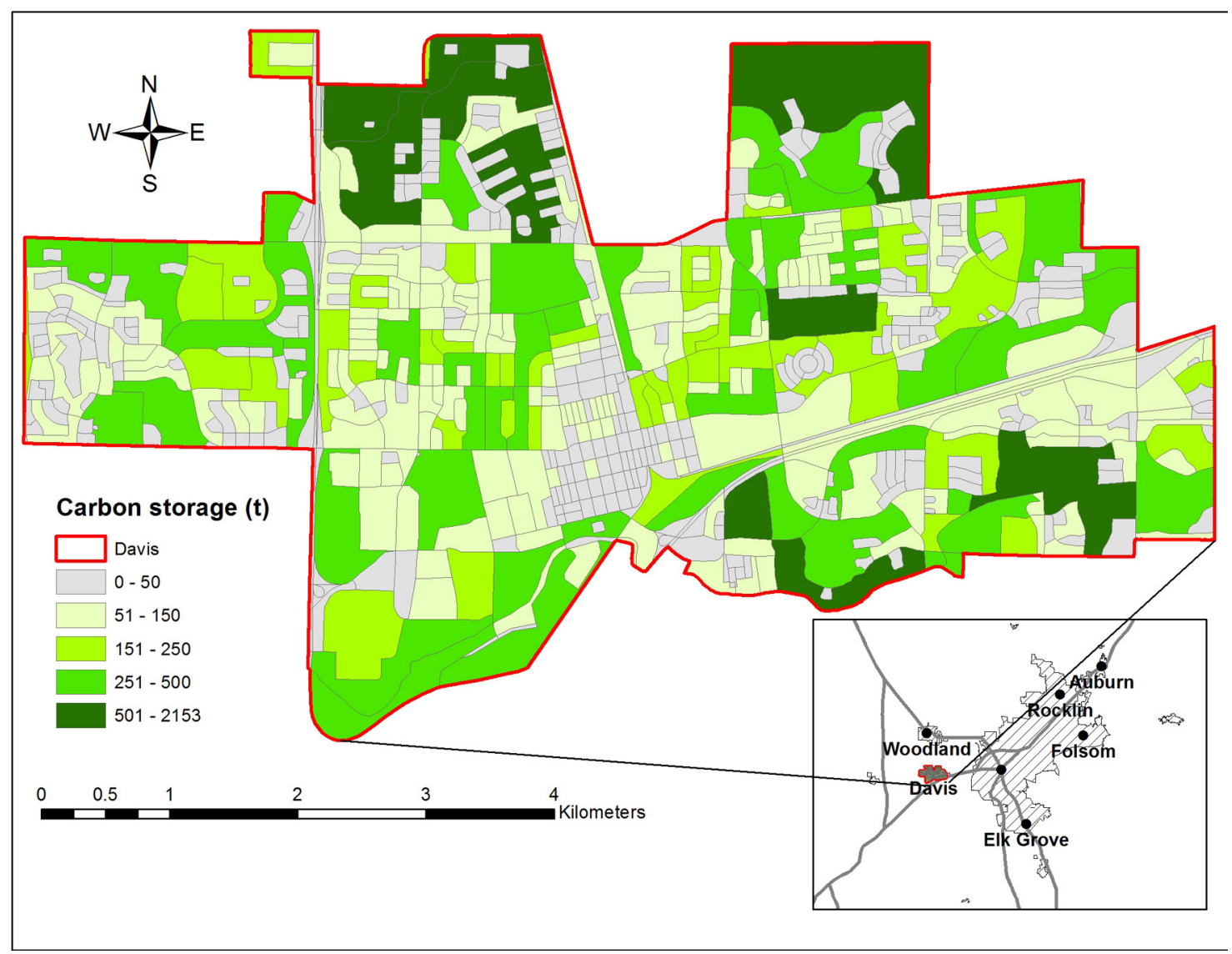

Fig. 6. Carbon stored by urban tree canopy in Davis, CA mapped by census block group.

\subsection{Uncertainty}

Estimates of UTC densities are subject to multiple sources of uncertainty. Measurement and sampling error influence the accuracy of data from field plots. Measurement errors (e.g., height measured with clinometer) have a relatively small effect, on the order of \pm 1 to 3 percent. In this study, standard errors are 5-15 percent of the estimates, indicating that sampling error is an important source of error. Martin, Chappelka, Somers, Loewenstein, and Keever (2013) found that 870 and 483 treed plots were needed to achieve estimates of carbon storage and sequestration with $\mathrm{a} \pm 10$ percent error, respectively. In this study there were only 201 treed plots in Los Angeles and 161 in Sacramento. By sampling a larger number of plots than were sampled here, ideally a minimum of 30 per land use/age class so that the distribution of the sample means approaches a normal distribution, error associated with differences between UTC over plots and UTC classified from the imagery can be reduced. Also, it is possible to increase sampling efficiency by stratifying the sample of plots based on a priori knowledge of the total amount of UTC in each land use/age class. Stratification can decrease the coefficient of variance for each stratum, allowing plots to be efficiently distributed and thereby reducing sample size needed to meet an allowable error.

Ketterings, Coe, van Noordwijk, Ambagau', and Palm (2001) describe several techniques for reducing uncertainty in the use of biomass equations, such as incorporation of site-specific dbh vs. height relations and wood density values. However, the lack of biometric data from urban trees weighed in the field remains a serious limitation to our ability to calibrate biomass equations and assign error estimates. In this study, differences between modeled and actual tree growth adds uncertainty to sequestration estimates.
Species assignment errors result from matching species not sampled to those sampled in the field for purposes of modeling size and growth. The magnitude of this error category depends on the proportion of population that must be assigned a species match, as well as goodness of fit in terms of matching size and annual growth rate. Given the attention paid during this study to assigning allometric equations, dry weight wood density values and species matching, estimates of carbon storage and sequestration may have uncertainty as great as \pm 10 percent (Aguaron \& McPherson, 2012).

Formulaic errors occur in modeling of energy effects from tree shade and climate modification. For example, relations between different levels of UTC and summertime air temperatures are not well-researched. Another source of error stems from differences between the airport climate data (i.e., Los Angeles International Airport) used to model energy effects and the actual climate of the study area (City of Los Angeles). Because of the uncertainty associated with modeling effects of tree shade on building microclimate and energy use, estimates of avoided emissions may be accurate within \pm 25 percent (California Air Resources Board, 2011; Hildebrandt \& Sarkovich, 1998).

Urban tree canopy classification error directly affects the accuracy of the analysis because transfer functions are applied to UTC polygons. The UTC estimation error, calculated as the difference between the classification and reference data divided by the total reference area, indicates the extent to which UTC is overestimated or underestimated. The UTC estimation error was relatively small for this study. For Los Angeles, UTC was overestimated by 0.6 percent UTC (UTC was $13.8 \%$ overall) and it was underestimated by 0.1 percent (UTC was $18.3 \%$ overall) for Sacramento. Other sources of uncertainty are associated with mapping land use/age classes and boundaries of GIS data sets, such as city limits and zoning classes. 
Mismatches among GIS data sets can result in misapplication of transfer functions. UTC classification accuracy can be improved with use of object-based image analysis systems, multiple-source data sets (i.e., LiDAR) and rigorous quality control (O'Neil-Dunne, MacFaden, Royar, \& Pelletier, 2012).

In summary, the transfer function approach makes it possible to map $C$ storage at higher spatial resolution than other approaches because it directly links to UTC and land use/age class. Given the limited number of field plots surveyed, sampling and estimation errors are relatively large, while measurement and UTC classification errors are relatively small. The bound of estimates reported here are conservative as the error estimates are based on sampling error, and do not include estimation error.

\section{Conclusions}

By sequestering $C$ city trees mitigate climate change and by modifying urban climate and conserving energy they are an effective adaptation strategy (Stone, 2012). Urban areas in California encompass 5 percent of the total land and support 95 percent of the population. Although the California Air Resources Board (2008) has adopted a tree planting project protocol for fungible offsets, its official statewide estimate of GHG emissions and sinks does not include urban forests. After applying the average storage density (11.8 tha $\left.\mathrm{th}^{-1}\right)$, sequestration $\left(0.68 \mathrm{tha}^{-1} \mathrm{yr}^{-1}\right)$ and avoided emissions $\left(0.44 \mathrm{tha}^{-1} \mathrm{yr}^{-1}\right)$ rates from this study to the state's 2.1 million ha of urban land, urban forests are estimated to store, sequester and avoid $C$ emissions of 25.1, 1.44 and 0.94 million $t$, respectively. By way of comparison, trees in California's 12.4 million ha of forest land were estimated to store and sequester 1214 and 10.5 million t, respectively (Wang \& Lin, 2012). Hence, urban forests are estimated to account for 2 and 12 percent of total $C$ stored and sequestered annually by trees in California. If avoided emissions are included, urban forests are responsible for 20 percent of total reductions. They act as an important sink for approximately 1-2 percent of statewide emissions (163 million $\mathrm{t}$ ), and warrant inclusion in the next forest inventory.

The primary contribution of this paper is methodological; the derivation and application of UTC-based transfer functions. When supported by ample field sampling and accurate UTC delineation, transfer functions improve $C$ calculations by incorporating effects of age-related differences in species composition and stand structure among low density residential age classes and other land uses. They can be used to map baseline $C$ storage levels for climate action planning, identify conservation areas where UTC densities are highest and determine where opportunities for expanding UTC are greatest. Combining remote sensing and ground-based measurements in a consistent manner can accurately document trends in urban forest mortality, in-growth, regeneration and planting. Spatially explicit documentation of environmental and social conditions can be used to link changes in UTC and C storage to causal drivers such as levels of community tree planting, drought, pests, storms and vandalism. Moreover, the transfer function approach can provide an analytical framework for quantifying, monetizing and mapping the value of other ecosystem services that urban forests provide, such as rainfall interception and air pollutant reduction (McPherson, Simpson, Peper, Maco, \& Xiao, 2005).

\section{Acknowledgements}

We would like to thank the City of Los Angeles, Sacramento Metropolitan Air Quality Management District and the Sacramento Tree Foundation for their support, as well as the more than 90 volunteers and staff who contributed to the tree survey and other aspects of the study. David Nowak and colleagues with the U.S.
Forest Service's Northern Research Station were very kind to share their information from the UFORE analyses, and Lorraine Weller (UC Riverside) and Antonio Davila (USFS) led field data collection in Los Angeles. Lisa Sarno and George Gonzalez, both with the City of Los Angeles provided support and guidance.

\section{References}

Aguaron, E., \& McPherson, E. G. (2012). Comparison of methods for estimating carbon dioxide storage by Sacramento's urban forest. In R. Lal, \& B. Augustin (Eds.), Carbon sequestration in urban ecosystems (pp. 43-71). Dordrecht, Netherlands: Springer.

Berland, A. (2012). Long-term urbanization effects on tree canopy cover along an urban-rural gradient. Urban Ecosystems, http://dx.doi.org/10 1007/ s11252-012-0224-9

Brack, C. L., \& Richards, G. P. (2002). Carbon accounting model for forests in Australia. Environmental Pollution, 116, S187-S194. http://dx.doi.org/10.1016/ s0269-7491(01)00250-0

Brookshire, D. S., \& Neill, H. R. (1992). Benefit transfers: Conceptual and empirical issues. Water Resources Research, 28(3), 651-655. http://dx.doi.org/ 10.1029/91wr02590

Cairns, M. A., Brown, S., Helmer, E. H., \& Baumgardner, G. A. (1997). Root biomass allocation in the world's upland forests. Oecologia, 111.

California Air Resources Board. (2008). Climate change scoping plan. Sacramento, CA: California Air Resources Board.

California Air Resources Board. (2011). Compliance offset protocol: Urban forest projects. Sacramento, CA: California Air Resources Board.

Chaparro, L., \& Terradas, J. (2009). Ecological services of urban forest in Barcelona. Bellaterra, Spain: Centre de Recerca Ecologica i, Aplicacions Forestals, Universitat Autonoma de Barcelona.

Climate Action Reserve. (2010). Urban forest project protocol. Version 1.1. Los Angeles: Climate Action Reserve.

Conway, T. M., Shakeel, T., \& Atallah, J. (2011). Community groups and urban forestry activity: drivers of uneven canopy cover? Landscape and Urban Planning, 101(4), 321-329. http://dx.doi.org/10.1016/j.landurbplan.2011.02.037

Cox, W. (2012). New US urban area data released. Newgeography. Retrieved from newgeography website: http://www.newgeography.com/content/002747new-us-urban-area-data-released

Downing, M. \& Ozuna, T. (1996). Testing the reliability of the benefit function transfer approach. Journal of Environmental Economics and Management, 30, 316-322.

Escobedo, F., Varela, S., Zhao, M., Wagner, J. E., \& Zipperer, W. (2010). Analyzing the efficacy of subtropical urban forests in offsetting carbon emissions from cities. Environmental Science and Policy, 13(5), 362-372. http://dx.doi.org/10.1016/j.envsci.2010.03.009

Gillespie, T. J., Pincetl, S., Brossard, S., Smith, J., Saatchi, S., Pataki, D., et al. (2012). A time series of urban forestry in Los Angeles. Urban Ecosystems, 15(1), 233-246. http://dx.doi.org/10.1007/s11252-011-0183-6

Grove, J. M., Cadenasso, M. L., Burch, W. R., Jr., Pickett, S. T., Schwarz, K., O’Neil-Dunne, J., et al. (2006). Data and methods comparing social structure and vegetation structure of urban neighborhoods in Baltimore, Maryland. Society and Natural Resources, 19, 117-136.

Heath, L. S., Smith, J. E., Skog, K. E., Nowak, D. J., \& Woodall, C. W. (2011). Managed forest carbon estimates for the US greenhouse gas inventory 1990-2008. Journal of Forestry, 109(3), 167-173.

Hildebrandt, E. W., \& Sarkovich, M. (1998). Assessing the cost-effectiveness of SMUD's shade tree program. Atmospheric Environment, 32, 85-94.

Hope, D., Gries, C., Zhu, W., Fagan, W. F., Redman, C. L., Grimm, N. B., et al. (2003). Socio-economics drive urban plant diversity. Proceedings of the National Academy of Sciences, 100.

Husch, B., Miller, C. I., \& Beers, T. W. (1982). Forest mensuration. New York, NY: John Wiley and Sons.

Jenkins, J. C., Chojnacky, D. C., Heath, L. S., \& Birdsey, R. A. (2003a). Comprehensive database of diameter-based biomass regressions for North American tree species (Gen. Tech. Rep/NE-319). Newtown Square, PA: US Department of Agriculture, Forest Service, Northeastern Research Station.

Jenkins, J. C., Chojnacky, D. C., Heath, L. S., \& Birdsey, R. A. (2003b). National-scale biomass estimators for United States tree species. Forest Science, 49(1), 12-35.

Jo, H. K. (2002). Impacts of urban greenspace on offsetting carbon emissions for middle Korea. Journal of Environmental Management, 64(2), 115-126. http://dx.doi.org/10.1006/jema.2001.0491

Jo, H. K., \& McPherson, E. G. (1995). Carbon storage and flux in urban residential greenspace. Journal of Environmental Management, 45, 109-133.

Ketterings, Q. M., Coe, R., van Noordwijk, M., Ambagau', Y., \& Palm, C. A. (2001). Reducing uncertainty in the use of allometric biomass equations for predicting above-ground tree biomass in mixed secondary forests. Forest Ecology and Management, 146(1-3), 199-209. http://dx.doi.org/ 10.1016/S0378-1127(00)00460-6

Kohavi, R., \& Provost, F. (1998). Glossary of terms. Machine Learning, 30, 271-274.

Lefsky, M., \& McHale, M. (2008). Volume estimates of trees with complex architecture from terrestrial laser scanning. Journal of Applied Remote Sensing, 2, 023521. http://dx.doi.org/10.1117/1.2939008

Lieth, H., Lieth, H., \& Whittaker, R. H. (1975). Modeling the primary productivity of the world. Primary productivity of the biosphere. New York: Springer-Verlag New York Inc. 
Liu, C. F., \& Li, X. M. (2012). Carbon storage and sequestration by urban forests in Shenyang, China. Urban Forestry and Urban Greening, 11(2), 121-128. http://dx.doi.org/10.1016/j.ufug.2011.03.002

Lowry, J. H., Baker, M. E., \& Ramsey, R. D. (2012). Determinants of urban tree canopy in residential neighborhoods: Household characteristics, urban form, and the geophysical landscape. Urban Ecosystems, 15(1), 247-266. http://dx.doi.org/10.1007/s11252-011-0185-4

Markwardt, L. J., \& Wilson, T. R. C. (1935). Strength and related properties of woods grown in the United States (Tech. Bull. No. 479). Madison, WI: USDA Forest Service, Forest Products Laboratory.

Martin, C. A., \& Stabler, L. B. (2004). Urban horticultural ecology: Interactions between plants, people and the physical environment. Acta Horticulturae, 639.

Martin, N. A., Chappelka, A. H., Somers, G., Loewenstein, E. F., \& Keever, G. J. (2013). Evaluation of sampling protocol for i-Tree Eco: A case study in predicting ecosystem services at Auburn University. Arboriculture and Urban Forestry, 39(2), 56-61.

McNeil, J., \& Vava, C. (2006). Oakville's urban forest: Our solution to pollution. Oakville, Ontario: Town of Oakville Parks and Open Space Department, Forestry Section.

McPherson, E. G. (1998). Atmospheric carbon dioxide reduction by Sacramento's urban forest. Journal of Arboriculture, 24(4), 215-223.

McPherson, E. G., \& Rowntree, R. A. (1993). Energy conservation potential of urban tree planting. Journal of Arboriculture, 19, 321-331.

McPherson, E. G., Simpson, J. R., Peper, P. J., Maco, S. E., \& Xiao, Q. (2005). Municipal forest benefits and costs in five U.S. cities. Journal of Forestry, 103, 411-416.

McPherson, G., Simpson, J., Marconett, D., Peper, P., \& Aguaron, E. (2008). Urban forestry and climate change. http://www.fs.fed.us/ccrc/topics/urban-forests/

McPherson, E. G., Simpson, J. R., Xiao, Q. F., \& Wu, C. X. (2011). Million trees Los Angeles canopy cover and benefit assessment. Landscape and Urban Planning, 99(1), 40-50. http://dx.doi.org/10.1016/j.landurbplan.2010.08.011

Myeong, S., Nowak, D. J., \& Duggin, M. J. (2006). A temporal analysis of urban forest carbon storage using remote sensing. Remote Sensing of Environment, 101(2), 277-282. http://dx.doi.org/10.1016/j.rse.2005.12.001

Nowak, D. J. (2005). Houston's regional forest: Structure, functions, values. Austin, TX: Texas Forest Service.

Nowak, D. J., \& Crane, D. (2002). Assessing urban forest effects and values: Toronto's urban forest. http://www.ufore.org/action/09-00.html (Retrieved 24.02.12)

Nowak, D. J., \& Crane, D. E. (2002). Carbon storage and sequestration by urban trees in the USA. Environmental Pollution, 116(3), 381-389. http://dx.doi.org/10.1016/s0269-7491(01)00214-7

Nowak, D. J., \& Greenfield, E. J. (2010a). Evaluating the National Land Cover Database tree canopy and impervious cover estimates across the conterminous United States: a comparison with photo-interpreted estimates. Environmental Management, 46(3), 378-390. http://dx.doi.org/10.1007/s00267-010-9536-9

Nowak, D. J., \& Greenfield, E. J. (2010b). Urban and community forests of the Pacific region: California, Oregon, Washington (Gen. Tech. Re. NRS-65). Newtown Square, PA: U.S. Department of Agriculture, Forest Service, Northern Research Station.

Nowak, D. J., Rowntree, R. A., McPherson, E. G., Sisinni, S. M., Kerkmann, E. R., \& Stevens, J. C. (1996). Measuring and analyzing urban tree cover. Landscape and Urban Planning, 36, 49-57.

Nowak, D. J., Crane, D. E., \& Stevens, J. C. (2001). Syracuse's urban forest resource. In D. J. Nowak, \& P. O'Connor (Eds.), Syracuse Urban Forest Master Plan: Guiding the City's Forest Resource in the 21st Century (pp. 9-14). Newtown Square, PA: U.S. Department of Agriculture, Forest Service Northeastern Research Station.

Nowak, D. J., Hoehn, R., Crane, D. E., Stevens, J. C., \& Walton, J. T. (2006a). Assessing urban forest effects and values: Casper WY's urban forest (Res. Bull. NRS-4). Newtown Square, PA: U.S. Department of Agriculture, Forest Service, Northern Research Station.

Nowak, D. J., Hoehn, R., Crane, D. E., Stevens, J. C., \& Walton, J. T. (2006b). Assessing urban forest effects and values: Minneapolis' urban forest (Res. Bull. NE-166). Newtown Square, PA: U.S. Department of Agriculture, Forest Service, Northern Research Station.

Nowak, D. J., Hoehn, R., Crane, D. E., Stevens, J. C., \& Walton, J. T. (2006c). Assessing urban forest effects and values: Washington DC's urban forest (Res. Bull. NRS-1). Newtown Square, PA: U.S. Department of Agriculture, Forest Service, Northern Research Station.

Nowak, D. J., Hoehn, R., Crane, D. E., Stevens, J. C., \& Walton, J. T. (2007a). Assessing urban forest effects and values: New York city's urban forest (Res. Bull. NRS-9). Newtown Square, PA: U.S. Department of Agriculture, Forest Service, Northern Research Station.

Nowak, D. J., Hoehn, R., Crane, D. E., Stevens, J. C., \& Walton, J. T. (2007b). Assessing urban forest effects and values: Philadelphia's urban forest (Res. Bull. NRS-7). Newtown Square, PA: U.S. Department of Agriculture, Forest Service, Northern Research Station.

Nowak, D. J., Hoehn, R. E., Crane, D. E., Stevens, J. C., \& Walton, J. T. (2007). Assessing urban forest effects and values: San Francisco's urban forest (Resource Bulletin NRS8). Newtown Square, PA: Northeastern Research Station, USDA Forest Service.

Nowak, D. J., Crane, D., Stevens, J., Hoehn, R., Walton, J., \& Bond, J. (2008). A ground-based method of assessing urban forest structure and ecosystem services. Arboriculture and Urban Forestry, 34(6), 347-358.
Nowak, D. J., Hoehn, R., Crane, D. E., Stevens, J. C., \& Cotrone, V. (2010). Assessing urban forest effects and values: Scranton's urban forest (Res. Bull. NRS-43). Newtown Square, PA: U.S. Department of Agriculture, Forest Service, Northern Research Station.

Nowak, D. J., Hoehn, R., Crane, D. E., Stevens, J. C., \& Fisher, C. L. (2010). Assessing urban forest effects and values: Chicago's urban forest (Res. Bull. NRS-37). Newtown Square, PA: U.S. Department of Agriculture, Forest Service, Northern Research Station.

Nowak, D. J., Hoehn, R. E., Crane, D. E., Weller, L., \& Davila, A. (2011). Assessing urban forest effects and values: Los Angeles' urban forest (Resource Bulletin NRS-47). Newtown Square, PA: U.S. Department of Agriculture, Forest Service, Northern Research Station.

O'Neil-Dunne, J. P. M., MacFaden, S. W., Royar, A. R., \& Pelletier, K. C. (2012). An object-based system for LiDAR data fusion and feature extraction. Geocarto International, http://dx.doi.org/10.1080/10106049.2012.689015

Palmer, J. F. (1984). Neighborhoods as stands in the urban forest. Urban Ecology, 8 , 229-241.

Peper, P. J., McPherson, E. G., \& Mori, S. M. (2001a). Equations for predicting diameter height, crown width and leaf area of San Joaquin Valley street trees. Journal of Arboriculture, 27(6), 306-317.

Peper, P. J., McPherson, E. G., \& Mori, S. M. (2001b). Predictive equations for dimensions and leaf area of coastal Southern California street trees. Journal of Arboriculture, 27(4), 169-180.

Pillsbury, N., Reimer, J. L., \& Thompson, R. (1998). Tree volume equations for fifteen urban species in California. San Luis Obispo: Urban forest ecosystems institute. California Polytechnic State University.

Raciti, S. M., Galvin, M. F., Grove, J. M., O’Neil-Dunne, J. P. M., Todd, A., \& Clagett S. (2006). Urban tree canopy goal setting: A guide for Chesapeake Bay communities. Annapolis, MD: USDA Forest Service, Northeastern Area, State and Private Forestry.

Raciti, S. M., Hutyra, L. R., Rao, P., \& Finzi, A. C. (2012). Inconsistent definitions of urban result in different conclusions about the size of urban carbon and nitrogen stocks. Ecological Applications, 22(3), 1015-1035.

Ryan, M. G., Harmon, M. E., Birdsey, R. A., Giardina, C. P., Heath, L. S., Houghton, R. A., et al. (2010). A synthesis of the science on forests and carbon for U.S. forests. Issues in Ecology, 13, 1-16.

Sanders, R. A. (1984). Some determinants of urban forest structure. Urban Ecology, 8, 13-27.

Simpson, W. T. (1993). Specific gravity, moisture content, and density relationship for wood (Gen. Tech. Rep. FPR-GTR-76). Madison, WI: U.S. Dept. of Agric., Forest Service, Forest Products Laboratory.

Simpson, J. R. (2002). Improved estimates of tree shade effects on residential energy use. Energy and Buildings, 34(10), 1073-1082.

Stone, B. (2012). The city and the coming climate: Climate change in the places we live New York: Cambridge University Press.

Strohbach, M. W., \& Haase, D. (2012). Above-ground carbon storage by urban trees in Leipzig, Germany: Analysis of patterns in a European city. Landscape and Urban Planning, 105(1-2) http://dx.doi.org/10.1016/j.landurbplan. 2011.12.018 184-184

Urban Forest Ecosystems Institute. (1995-2012, January). SelecTree. California Polytechnic State University. Retrieved from http://selectree.calpoly.edu/

Wang, Y.-C., \& Lin, J.-C. (2012). Air quality enhancement zones in Taiwan: A carbon reduction benefit assessment. Forest Policy and Economics, 23(0), 40-45. http://dx.doi.org/10.1016/j.forpol.2012.07.009

Wenger, K. F. (1984). Forestry handbook. New York. NY: John Wiley and Sons

Xiao, Q., \& McPherson, E. G. (2005). Tree health mapping with multispectral remote sensing data at UC Davis, California. Urban Ecosystems, 8(3-4), 349-361.

Xiao, Q., Ustin, S., McPherson, E., Peper, P., \& Green, R. O. (1999). Characterization of the structure and species composition of urban trees using high resolution AVIRIS data. In Summaries of the eight JPL airborne earth science workshop (pp. 451-460). Pasadena, CA: California Institute of Technology Jet Propulsion Laboratory.

Xiao, Q., Wu, C., Simpson, J., \& McPherson, E. G. (2009). Urban forests for clean air demonstration project - Land cover, land use and urban forest analysis. Davis, CA: Department of Land, Air and Water Resources, UC Davis (Final report).

Yang, J., McBride, J., Zhou, J., \& Sun, Z. (2005). The urban forest in Beijing and its role in air pollution reduction. Urban Forestry and Urban Greening, 3, 65-78.

Yesilonis, I. D., \& Pouyat, R. V.(2012). Carbon stocks in urban forest remnants: Atlanta and Baltimore as case studies. In R. Lal, \& B. Augustin (Eds.), Carbon sequestration in urban ecosystems (pp. 103-120). Dordrecht, Netherlands: Springer.

Zhao, M., Kong, Z. H., Escobedo, F. J., \& Gao, J. (2010). Impacts of urban forests on offsetting carbon emissions from industrial energy use in Hangzhou, China. Journal of Environmental Management, 91(4), 807-813. http://dx.doi.org/10.1016/j.jenvman.2009.10.010

Zipperer, W. C., Sisinni, S. M., Pouyat, R. V., \& Foresman, T. W. (1997). Urban tree cover: An ecological perspective. Urban Ecosystems, 1(4), 229-246. http://dx.doi.org/10.1023/a:1018587830636 